"Better Policies" series

Addressing the

Competitiveness Challenges in Germany and the Euro Area

OCTOBER 2012

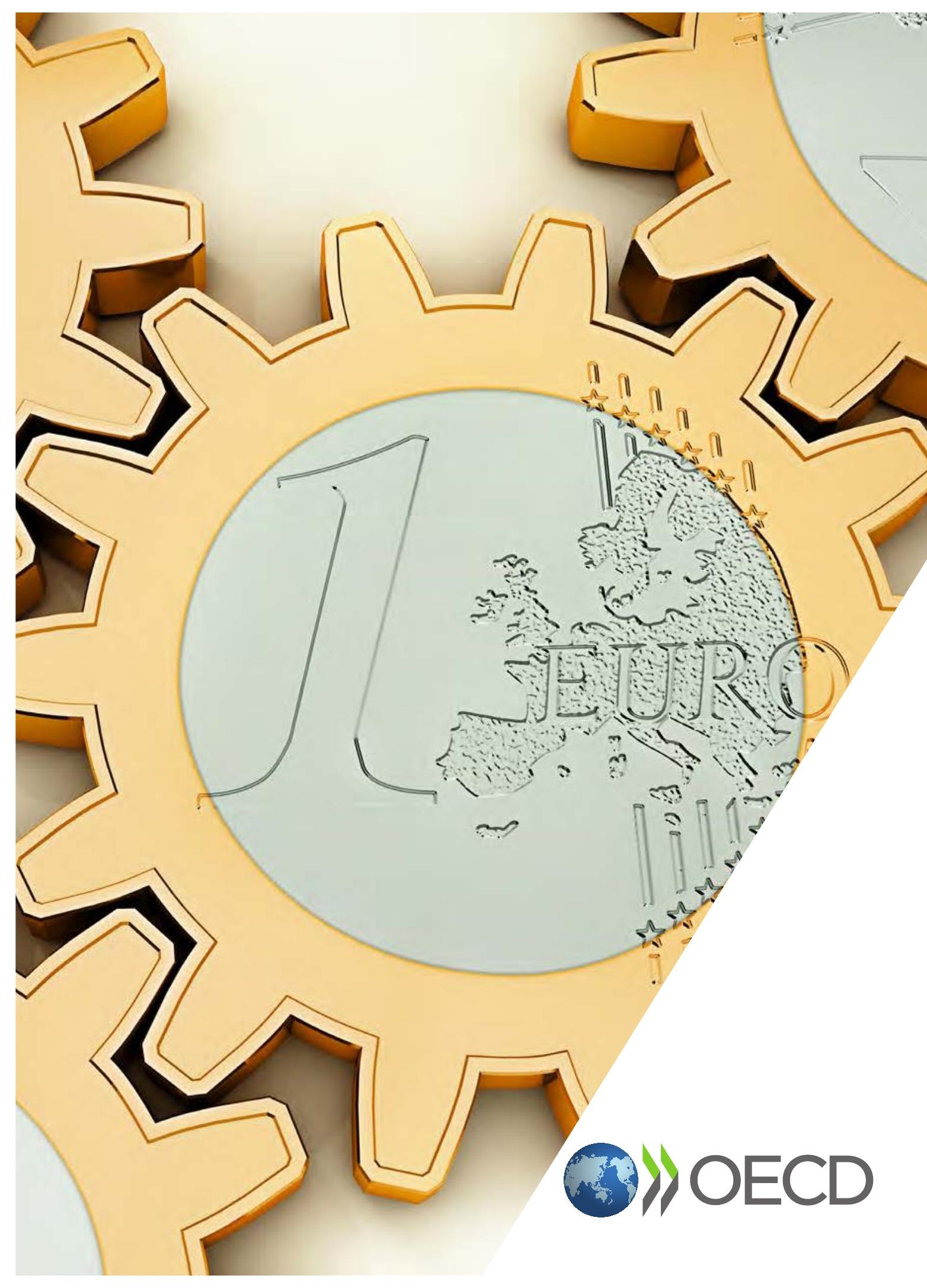


Better Policies

\section{Addressing \\ the Competitiveness Challenges in Germany and the Euro Area}


This work is published on the responsibility of the Secretary-General of the OECD. The opinions expressed and arguments employed herein do not necessarily reflect the official views of the Organisation or of the governments of its member countries.

This document and any map included herein are without prejudice to the status of or sovereignty over any territory, to the delimitation of international frontiers and boundaries and to the name of any territory, city or area.

ISBN 978-92-64-20164-4 (PDF)

Series: Better Policies

ISSN 2308-1392 (online)

The statistical data for Israel are supplied by and under the responsibility of the relevant Israeli authorities. The use of such data by the OECD is without prejudice to the status of the Golan Heights, East Jerusalem and Israeli settlements in the West Bank under the terms of international law.

Photo credits: Cover (c) Euro-Zahnrad @ arahan - fotolia.com

Corrigenda to OECD publications may be found on line at: www.oecd.org/publishing/corrigenda.

(c) OECD 2013

You can copy, download or print OECD content for your own use, and you can include excerpts from OECD publications, databases and multimedia products in your own documents, presentations, blogs, websites and teaching materials, provided that suitable acknowledgment of the source and copyright owner is given. All requests for public or commercial use and translation rights should be submitted to rights@oecd.org. Requests for permission to photocopy portions of this material for public or commercial use shall be addressed directly to the Copyright Clearance Center (CCC) at info@copyright.com or the Centre français d'exploitation du droit de copie (CFC) at contact@cfcopies.com. 


\section{이) $\mathrm{OECD}$}

\section{Addressing the Competitiveness Challenges in Germany and the Euro Area}

\section{Contents}

SUMMARY AND MAIN CONCLUSIONS
INTRODUCTION
THE EUROPEAN PERFORMANCE IN COMPARISON
LONG-TERM PROSPECTS POINT TO A WEAKER PERFORMANCE
RESTORING COMPETITIVENESS AND ADDRESSING IMBALANCES IN THE EURO AREA
SUPPORTING INNOVATION AND KNOWLEDGE BASED CAPITALL
STRENGTHENING COMPETITION IN PRODUCT MARKETSS
INVESTING IN HUMAN CAPITAL
IMPROVING THE FUNCTIONING OF LABOUR MARKETS
STATISTICAL ANNEXXRMING TAX SYSTEMS




\section{Summary and main conclusions}

The current crisis and deteriorating growth prospects in many countries make a competiveness enhancing reform agenda a conditio sine qua non to kick-off the European economy.

- The euro area is faced with the double challenge of addressing diverging competitiveness paths between its members and redressing it vis-à-vis the rest of world. Productivity gains over the past decade have been comparatively modest and even stagnant in some countries. Labour compensation at one extreme increased less than productivity in Germany and at the other exceeded it by a large margin in Ireland and Southern Europe, adding to the differences in competitiveness while driving the current account imbalances that have built up in the euro area.

- This calls for policy actions to boost productivity in all euro area countries, and to create mechanisms allowing for a stronger link between productivity gains and wages. Past OECD work has identified a number of areas where policy changes could help promote stronger and more balanced growth in the euro area: they include product and labour market reform, innovation, service liberalisation, investment in skills and education. European countries should therefore embark on a broad strategy to strengthen their productivity performance an act in all these areas. This is all the more important as Europe is competing with more dynamic regions in the world.

- Precise recommendations need to be adapted to each country's specific circumstances. For instance, in the surplus countries, including in Germany, adjustment requires greater reliance on domestic demand, including by reforms that could unlock opportunities for investment and consumption to contribute to the correction of imbalances in the region.

Such a strategy could not only enhance the growth and competiveness performance of European Countries, it would also contribute to a better balanced economy. The OECD stands ready to be a partner in the formulation and implementation of an agenda for inclusive growth and competitiveness in Europe. It is already working with each European country to support such a comprehensive reform agenda. 


\section{Introduction}

Almost all advanced OECD countries are faced with weak growth prospects. Therefore, restoring or further improving competitiveness has become a major policy objective. Stronger competitiveness is indeed an important way of delivering more robust growth, especially in those countries that have accumulated large external deficits and are now facing painful adjustments.

The euro area is faced with two competitiveness challenges. First, the region as a whole has become less competitive over the past decade: it is faced with slowing productivity growth and it has been losing export market share in global markets, while emerging countries have gained new markets and have moved up the value chain. Second, diverging trends in competitiveness between the countries in external deficit and those in external surplus have fuelled internal imbalances that are at the root of the current crisis. Some countries, such as Germany, are performing strongly largely as a result of important and sometimes difficult reforms that have been implemented since the 1990s.

The crisis has contributed to a partial correction of imbalances in the euro area. However, for these imbalances to be reduced durably, improvements in labour productivity and labour utilisation are urgently needed in the deficit countries. Policies to ensure that wages move in line with productivity are also essential. Competitiveness can also be improved by lowering non wage labour costs (i.e. taxes on labour) in countries that have the policy space, as long as this can be done in a budget neutral manner. In the surplus countries, adjustment requires greater reliance on domestic demand, including by reforms that could unlock opportunities for investment and consumption. More broadly, competitiveness-enhancing policies should go hand-in-hand with a more comprehensive agenda to improve living standards and the well-being of the population, foster social inclusiveness and fairness, and preserve the environment.

Against this background, this note presents a diagnosis of the medium-term performance of the euro area economies and the drivers of competitiveness. It then presents the key policy areas where actions could help remove obstacles to stronger growth in the euro area, promote competitiveness and reduce imbalances.

The OECD stands ready to support the design and implementation of these structural reforms. In particular, the OECD could, in cooperation with the EU, support the monitoring of the implementation of structural reforms in EU countries. For that it could rely on its existing system to monitor structural reforms through the Going for Growth country notes and the Economic Surveys, as well as the monitoring of structural reforms already done in the context of the G20. 


\section{The European performance in comparison}

\section{An average position in terms of GDP per capita with important cross country differences}

The euro area's per capita GDP is around $80 \%$ of the average level of the top half of OECD countries, below that of the G7, and close to the OECD average (Figure 1). But there is a wide gap between the best performers (Luxembourg, Netherlands) and Greece or Portugal whose GDP per capita is below $60 \%$ of the average level of the top half of OECD countries. Germany's per capita GDP at around $85 \%$ of the average level of the top half of OECD countries, is slightly below that of the G7, but at the top-end for the 3 largest euro area countries.

Among the largest 3 euro area countries France ranks first and well above the euro area average in terms of the level of labour productivity, either measured as GDP per employee or GDP per hour worked (Figures 2 and 3). Germany's productivity per worker is relatively low but it has a comparatively high productivity per hour worked. This reflects the fact that working hours per employee are lower than on average in the OECD (Figure 4), notably because of the importance of part-time employment.

Figure 1. GDP per capita in selected OECD countries

Average of upper half of OECD countries $=100,2011$

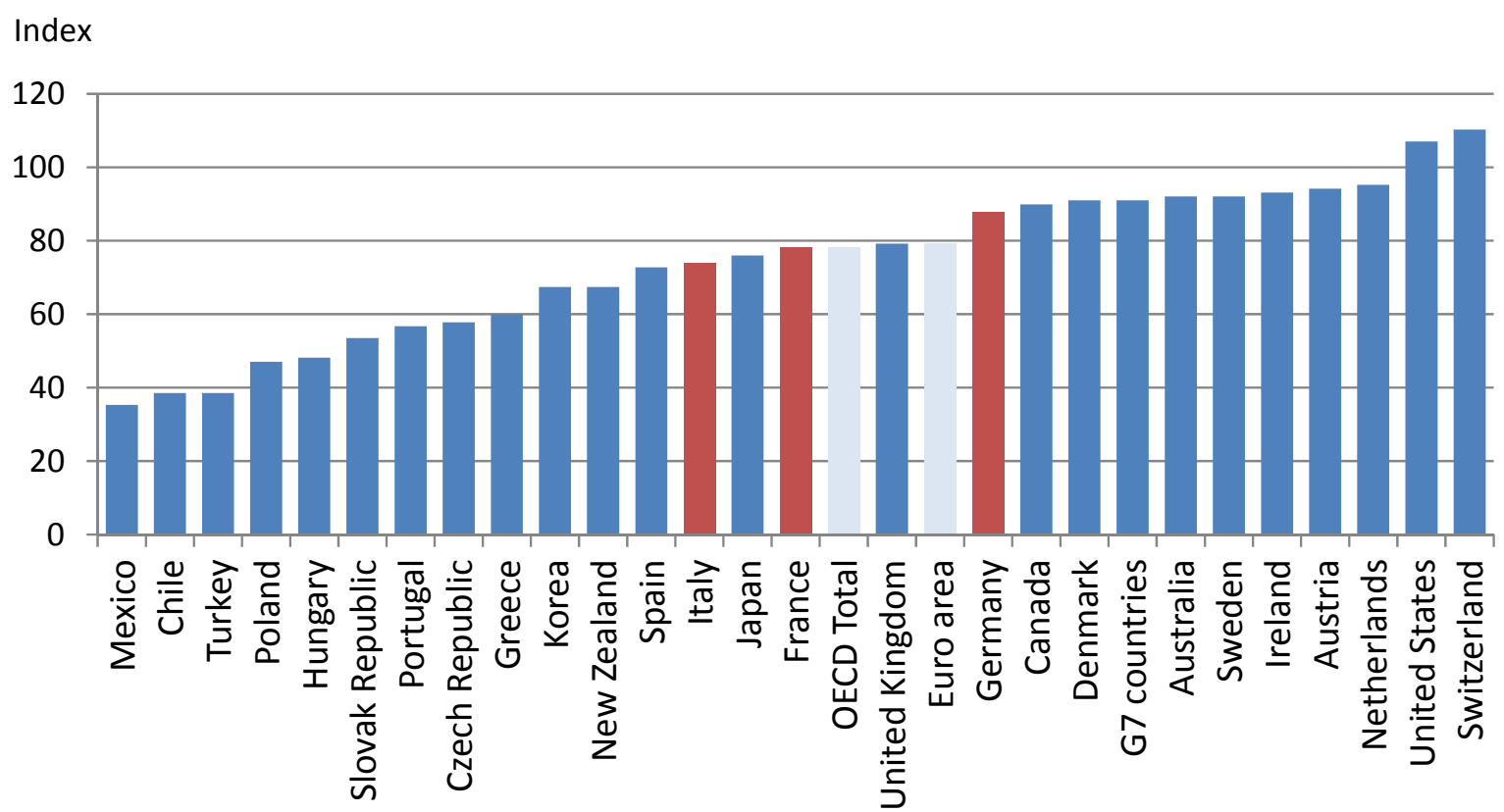

Source: OECD Productivity Database. 
Figure 2. Labour productivity levels in the total economy : GDP per total employment, in selected OECD countries

Average of upper half of OECD countries = 100, 2011

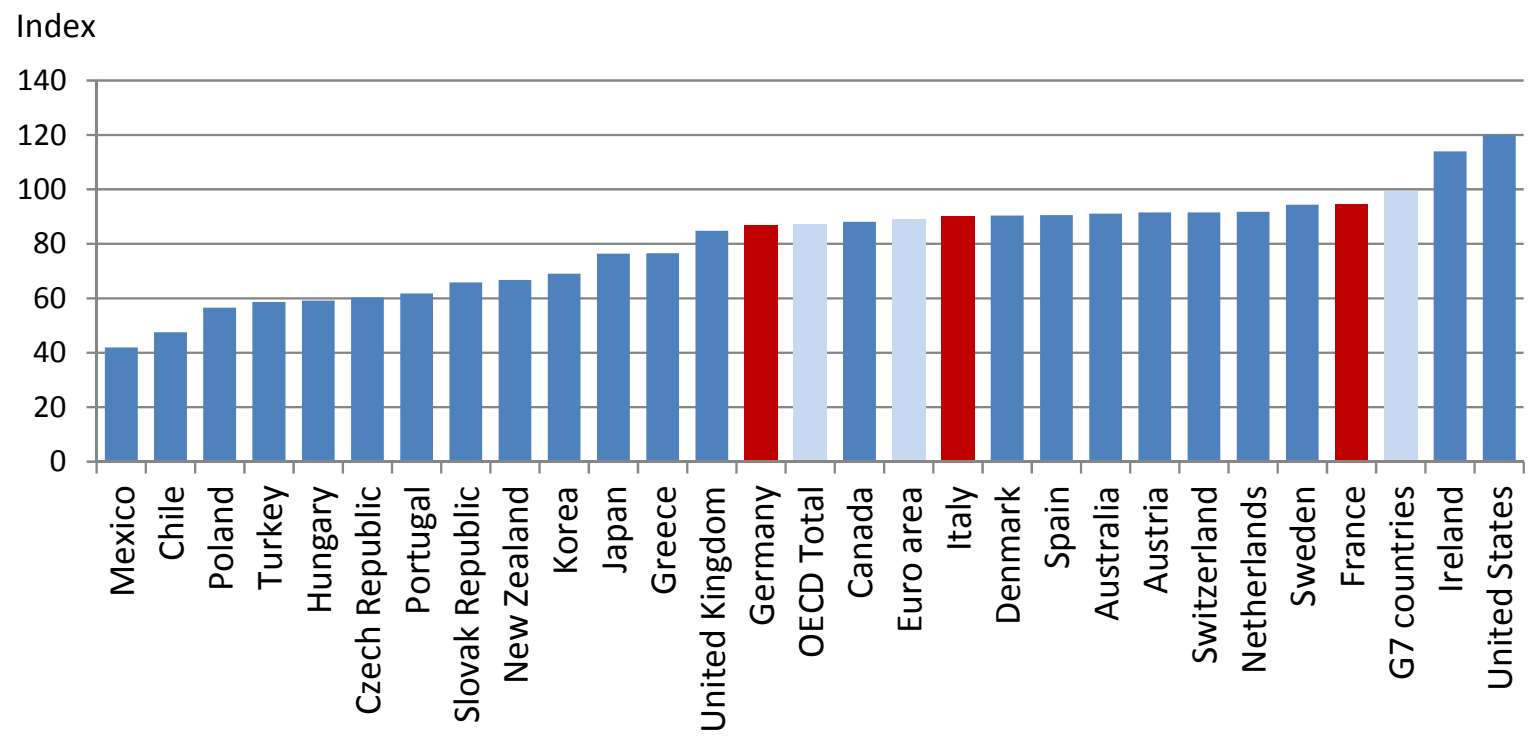

Source: OECD Productivity Database.

Figure 3. Hourly labour productivity levels (GDP per hours worked) in selected OECD countries

Average of upper half of OECD countries = 100, 2011

Index

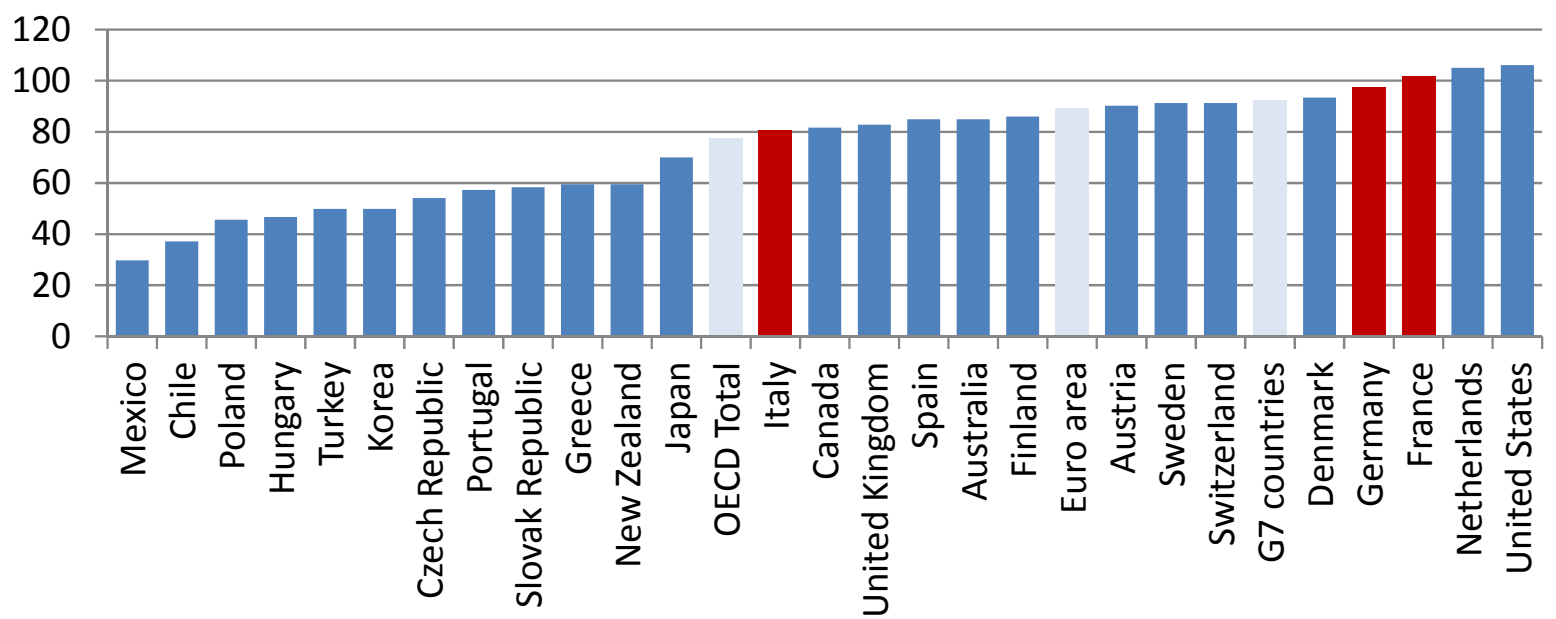

Note : This chart shows the gap between hourly labour productivity in each country and the average in the 17 OECD countries with the highest productivity. As productivity is especially high in Luxembourg and Norway (not represented here) only a few countries have an index above 100.

Source: OECD Productivity Database. 
The euro area suffers from a high gap in hours worked (Figure 4) which affect GDP per capita performance. This is particularly true in France. Thus is also the case in Germany despite the aboveaverage employment rate (Figure 5) resulting from the dual vocational education system which helps keeping youth unemployment among the lowest in the OECD and labour market reforms that have reduced the NAIRU by about $2 \frac{1}{2} 2$ percent.

Figure 4. Gap in hours worked per capita with respect to the average of the top half of OECD countries (2011)

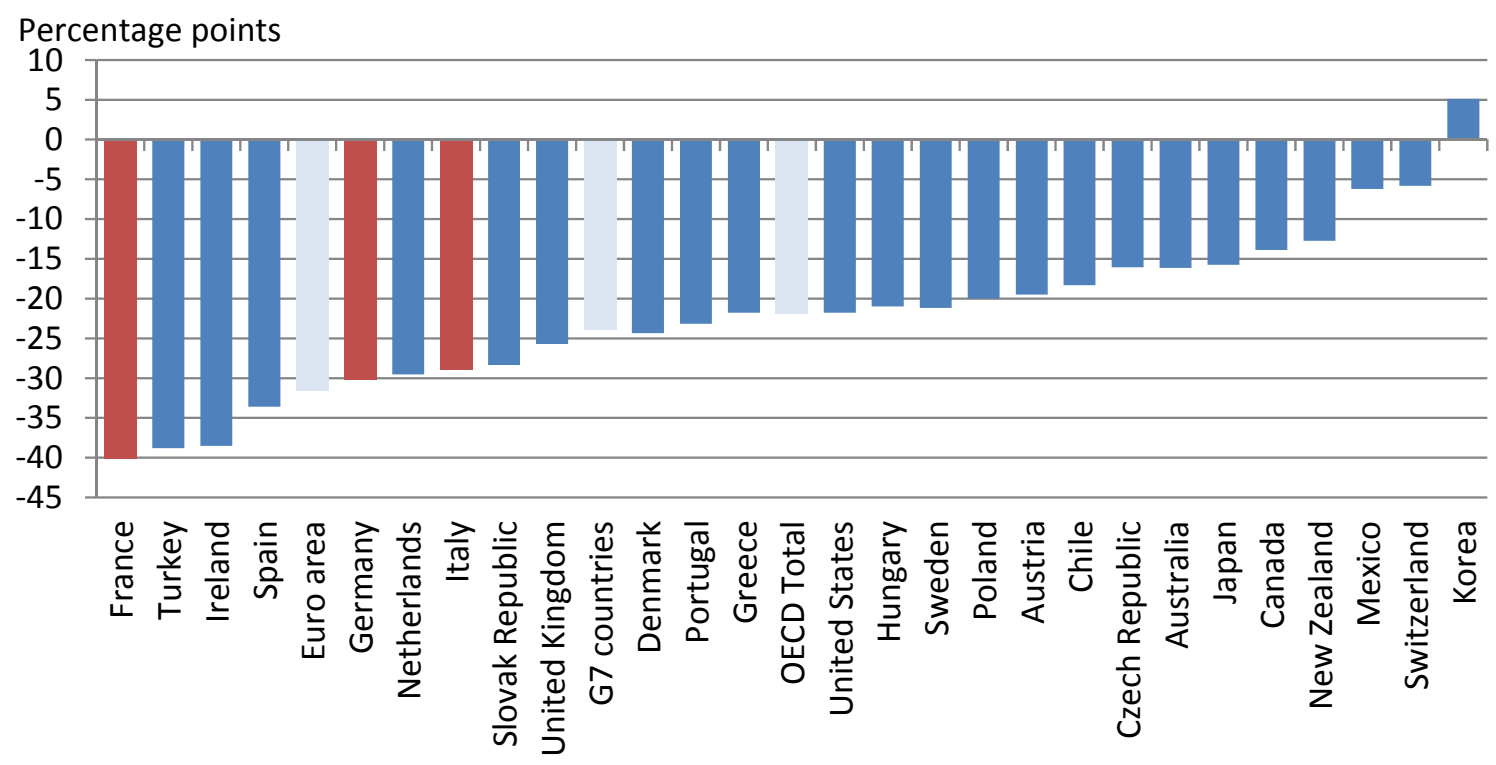

Note : This chart shows the gap between working hours in each country and average working hours in the 17 OECD countries with the longest hours worked. As working hours are especially high in Korea and Luxembourg (not represented here) only a few countries have a positive gap.

Source : OECD Productivity Database.

Figure 5. Employment rate

Ratio of employment to working age population, 2011

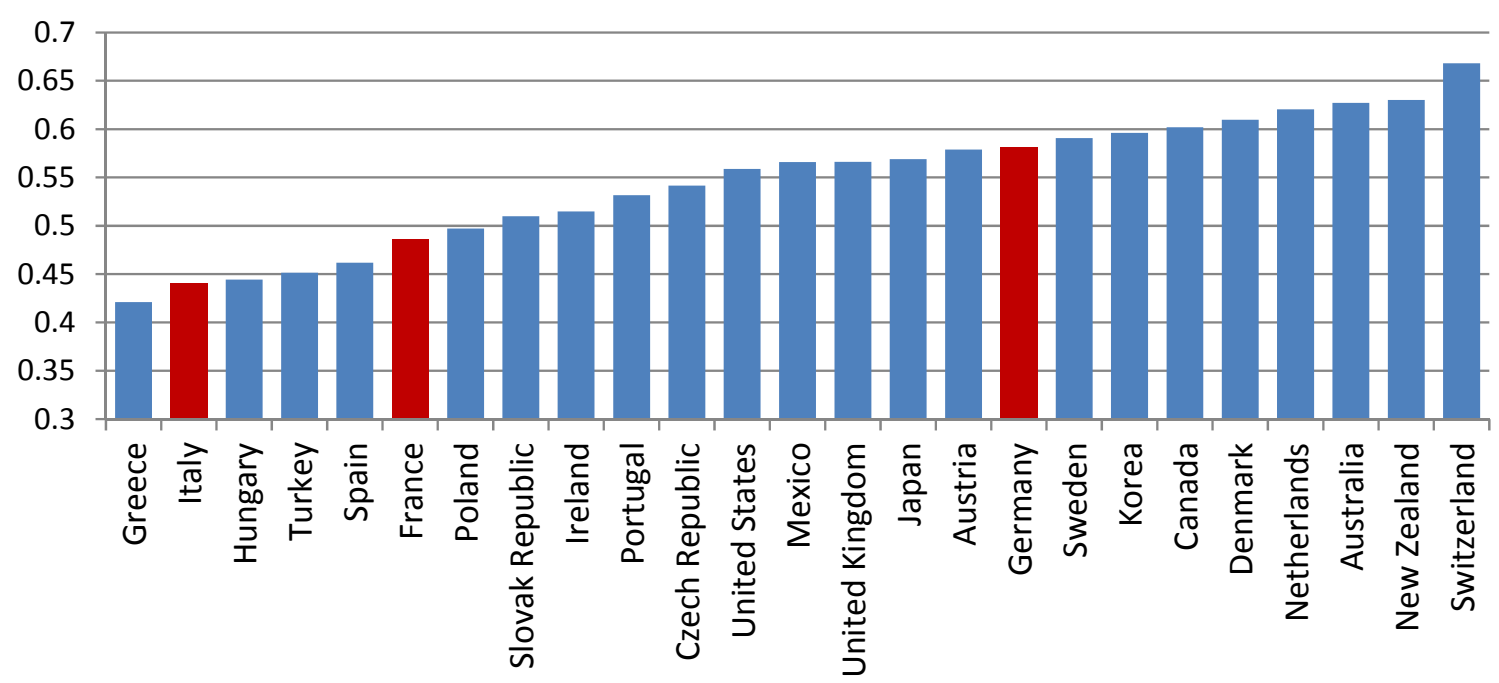

Source : Economic Outlook database. 
Low female participation in the labour market contributes to the low overall employment rate in Southern European countries (Figure 6) ; in other countries like Germany female participation in the labour market is high, but most work part-time. Low youth participation to the labour market contributes to the low overall employment rate in Southern European countries and France (Figure 7).

Figure 6. Women employment rate (2012Q2)

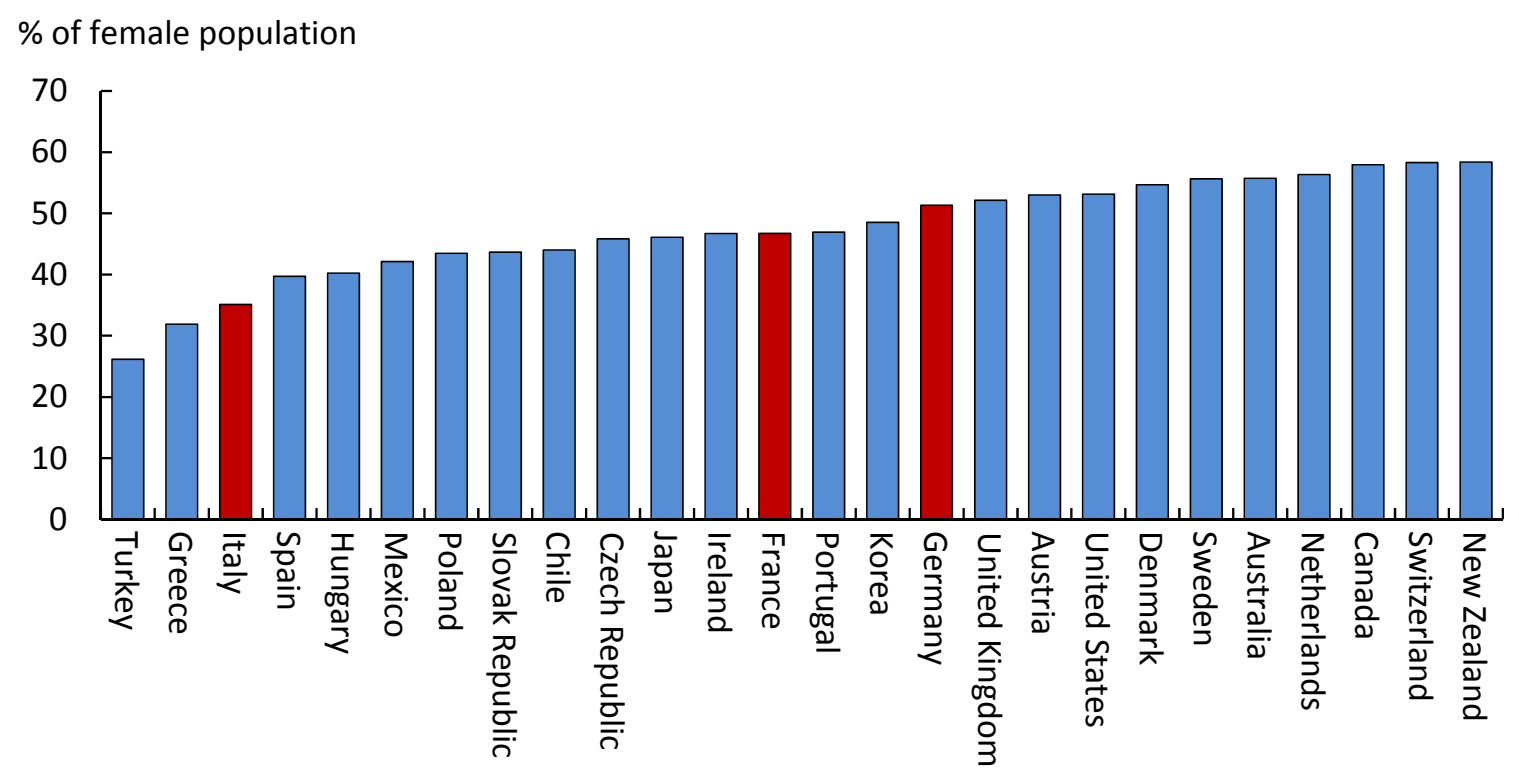

Figure 7. Youth employment and unemployment rates

A. Youth employment rate (2012Q2)

$\%$ of youth (aged 15-24)

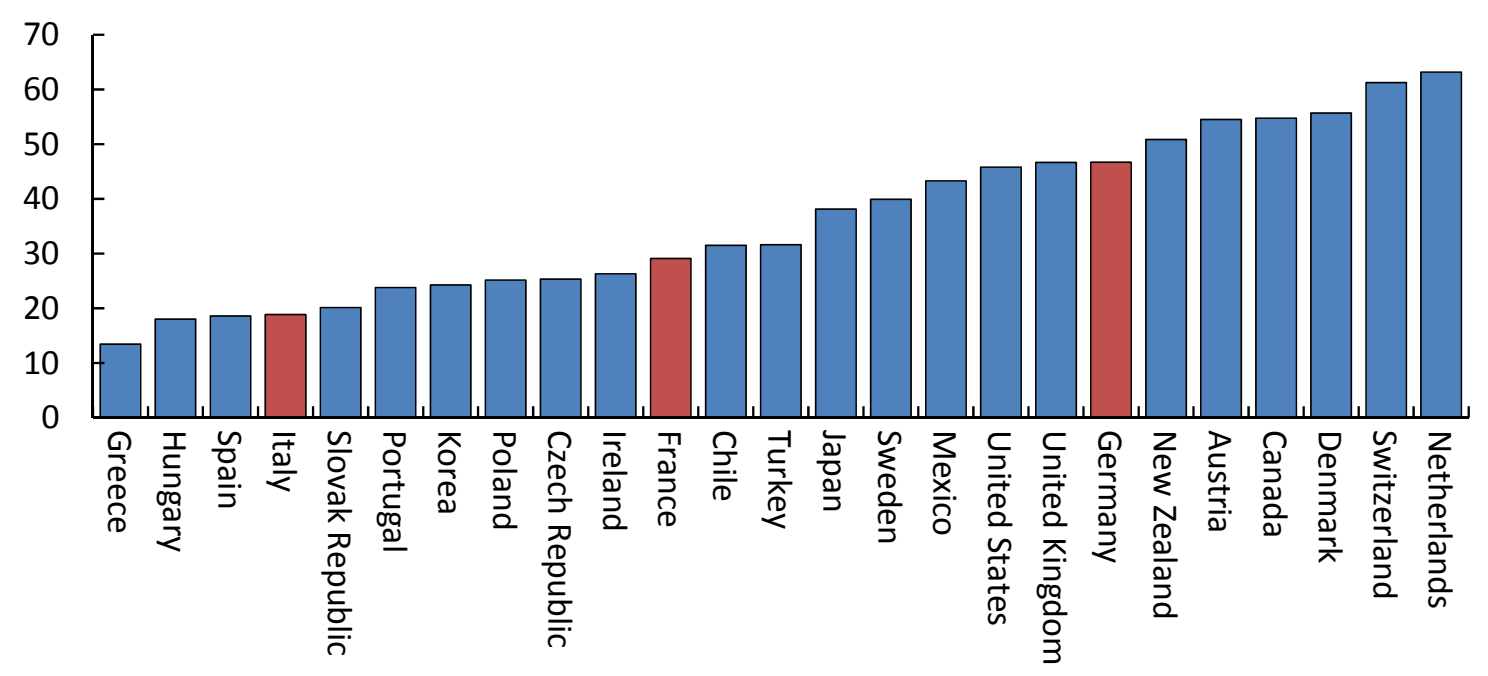




\section{B. Youth unemployment rate (2012Q2)}

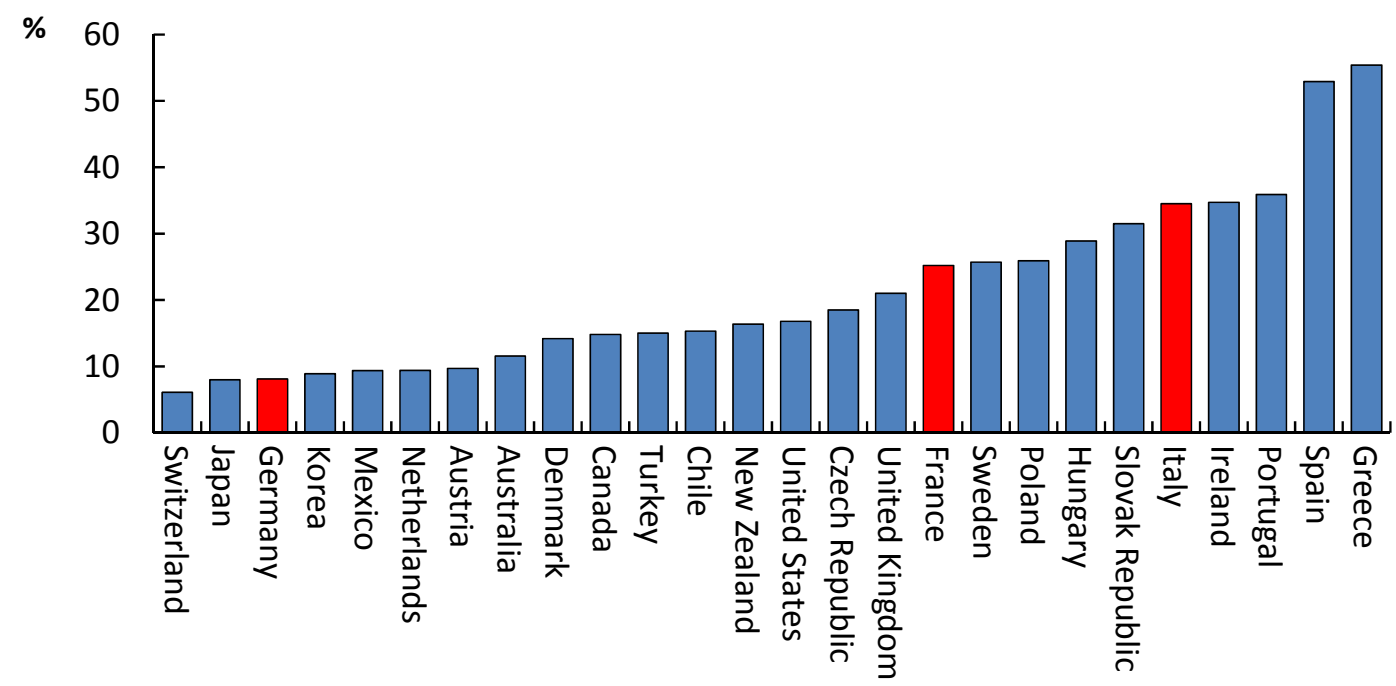

\section{An average productivity growth over the past decade}

The productivity gains in the euro area over the past decade have been modest (less than 1 percent a year on average) and well below the OECD average, Japan and the United-States (Figure 8). Productivity has notably stagnated in Italy and increased by only $1 \%$ in Germany and France. ${ }^{1}$ The performance of the peripheral countries has been stronger, but not commensurate to the gap in income levels, except in Ireland. Productivity gains were much stronger in the Eastern European countries reflecting their transition to market economies since the mid 1990s and impressive inward FDI flows. In general, in most euro area countries, this reflects low growth in multifactor productivity both in quantitative as well as in qualitative terms (high-tech, automotive industries) (Figure 9).

The sector breakdown of productivity gains shows some quite different patterns across countries. For instance, most of the productivity gains in Germany have been concentrated in the industrial sector while in France they were concentrated in the service sector (Figure A2 in the annex). Redressing the stagnant domestic services sector, which is not attractive enough for employment and investment and contributes little to economic growth, will be a key challenge for the German economy going forward. 
Figure 8. Average labour productivity growth in 2000-2011 (total economy)

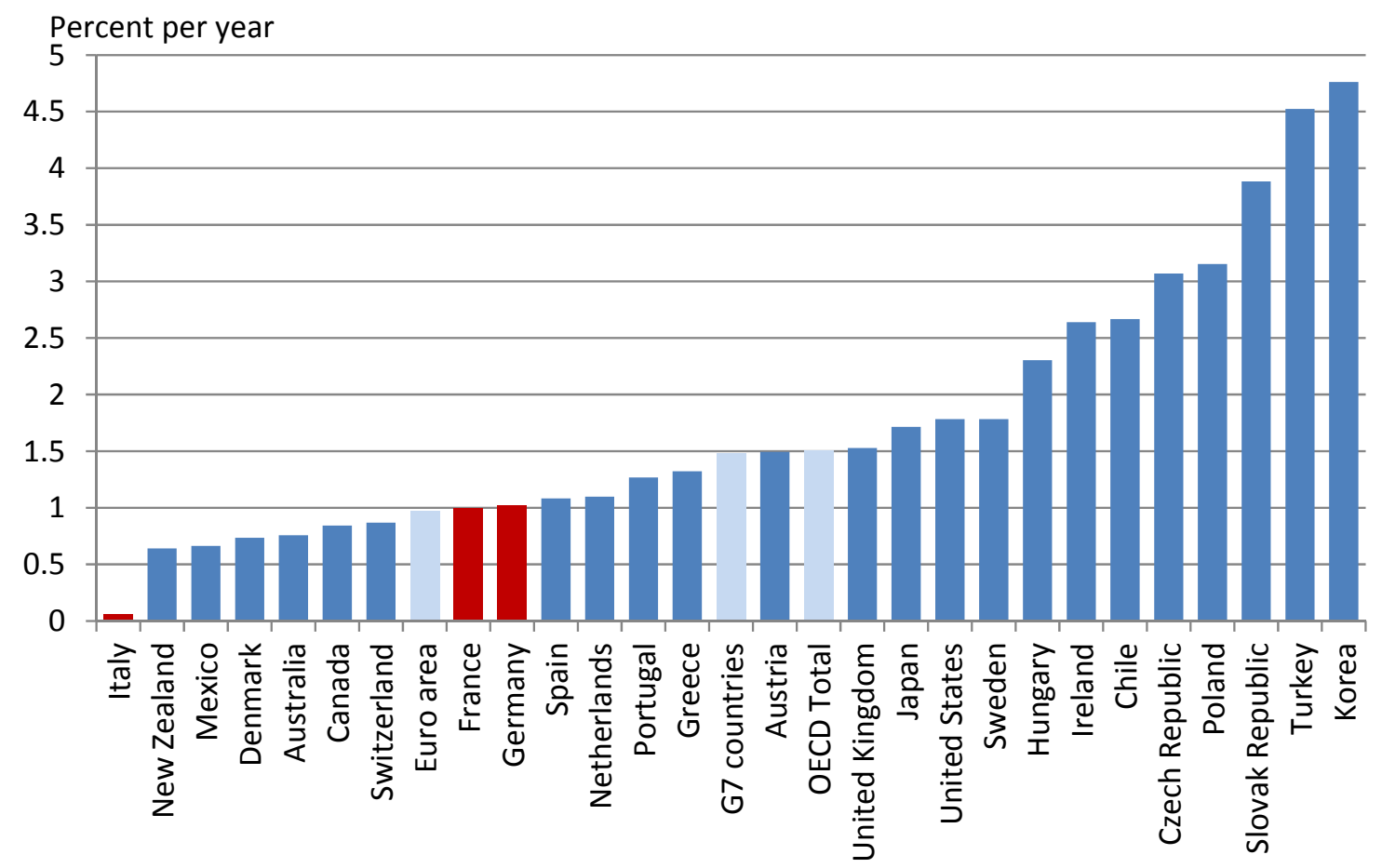

Source: OECD Productivity Database.

Figure 9. Decomposition of productivity growth (2001-2010)

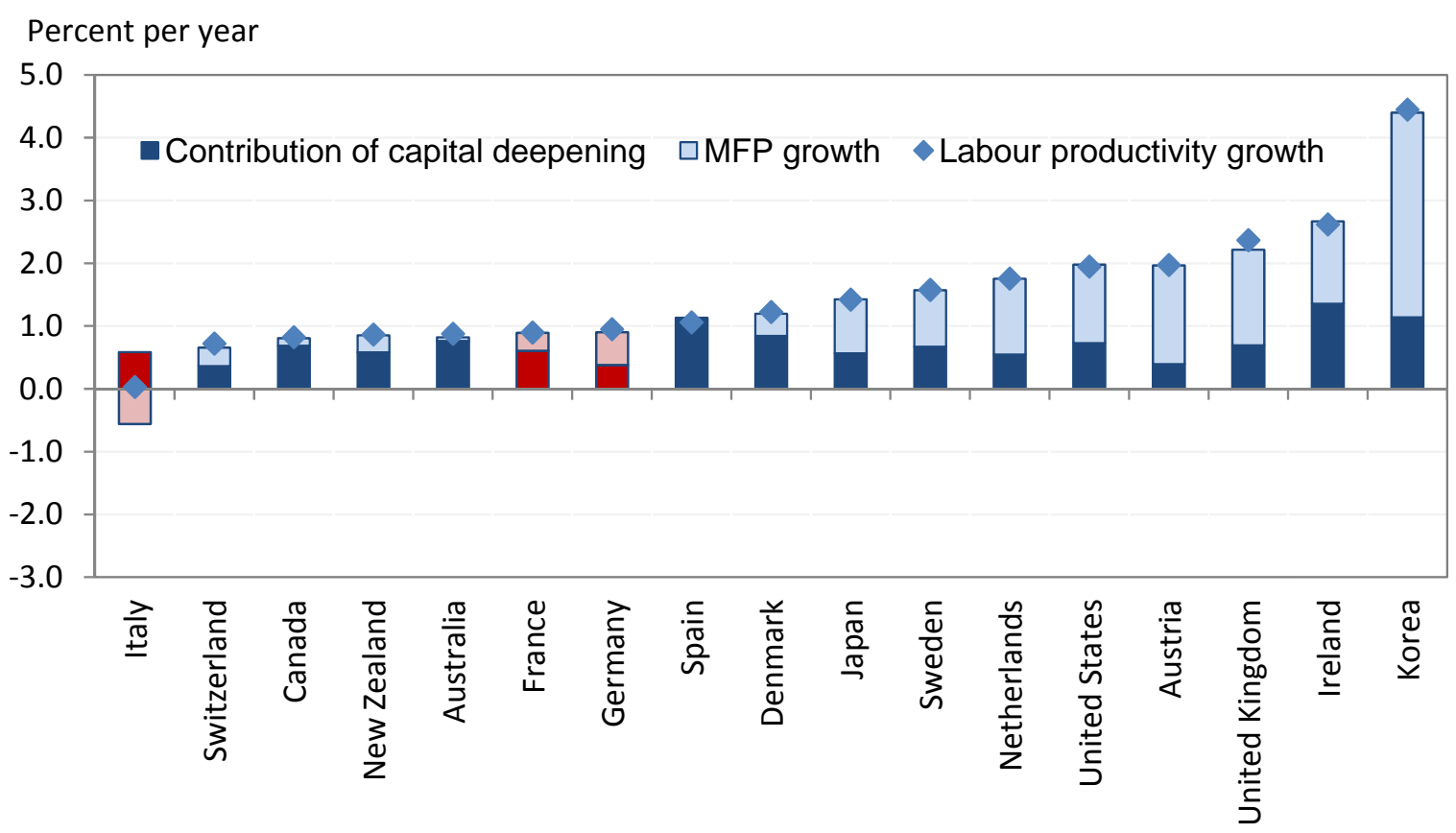

Source : OECD Productivity Database, October 2012. 


\section{Diverging trends in competitiveness}

The divergence in unit labour costs within the euro area mainly reflects a stronger divergence in labour compensation. On the one hand, labour compensation increased very modestly in Germany resulting in flat unit labour costs (ULC) in nominal terms since 2000 (Figures 10 and 11) ; unit labour costs even declined between 2001-07 as labour compensation growth was lower than productivity gains. This is exceptional in the euro area as well as in the OECD. Only Japan, a country in deflation, has posted lower ULC increases. As a result of wage moderation, Germany is also the only euro area country (with Finland) to have posted a decline in the real effective exchange rate over the past decade, in spite of a stronger euro area exchange rate vis-à-vis major economies like the United States, the United Kingdom and Japan (Figure 12).

By contrast, more dynamic labour compensation, despite moderate or stagnant productivity in some other countries in the euro area (including Greece, Italy, Portugal and Spain), has led to strong ULC growth over this period. This divergence has been the main driver of the trade and current account imbalances that have built up in the euro area since its inception. Since the crisis however, this divergence has started to reverse, reflecting both slower productivity gains and higher wage increases in Germany, and stronger productivity gains and more wage moderation in countries like Ireland and Spain. However, unit labour costs have not yet started to adjust downwards in France and Italy, where labour compensation growth continues to remain dynamic despite stagnant productivity.

Figure 10. Unit labour costs ${ }^{1}(2000=100)$

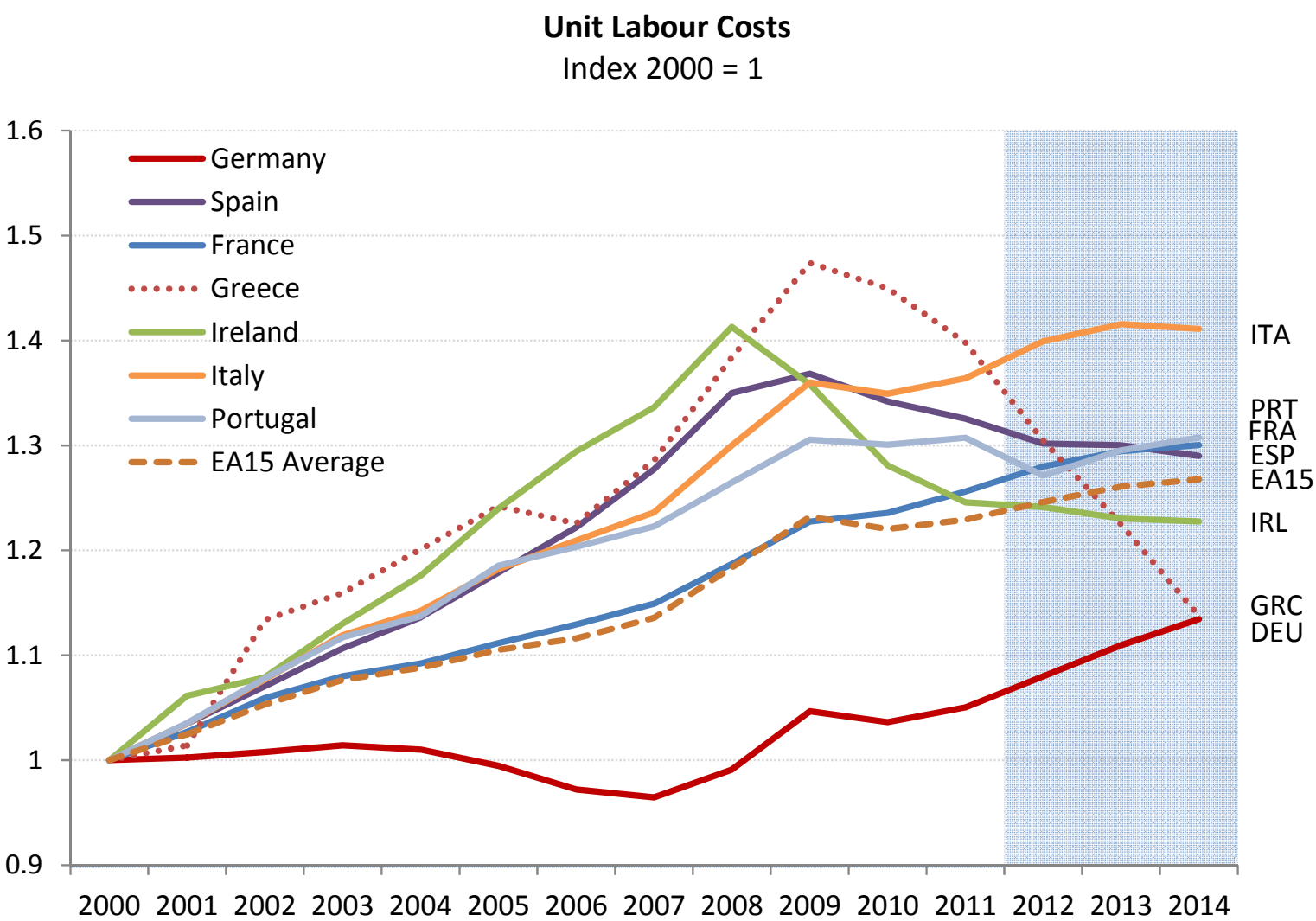

Note: The euro area 15 average is GDP-weighted. The figures for 2012 to 2014 are preliminary Economic Outlook 92 (November 2012) forecasts.

Source : OECD Economic Outlook database. 
Figure 11. Decomposition of unit labour costs, total economy, annual average growth $\%$

A. $2001-2011$

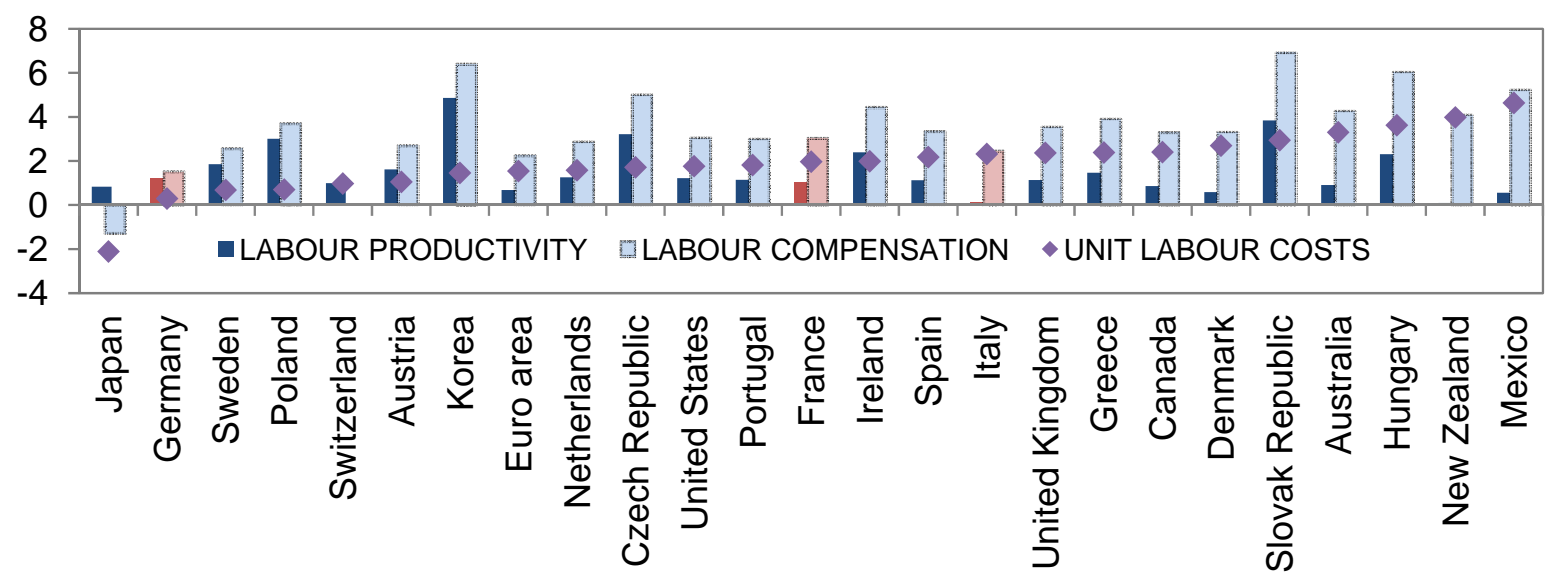

B. 2001-2007

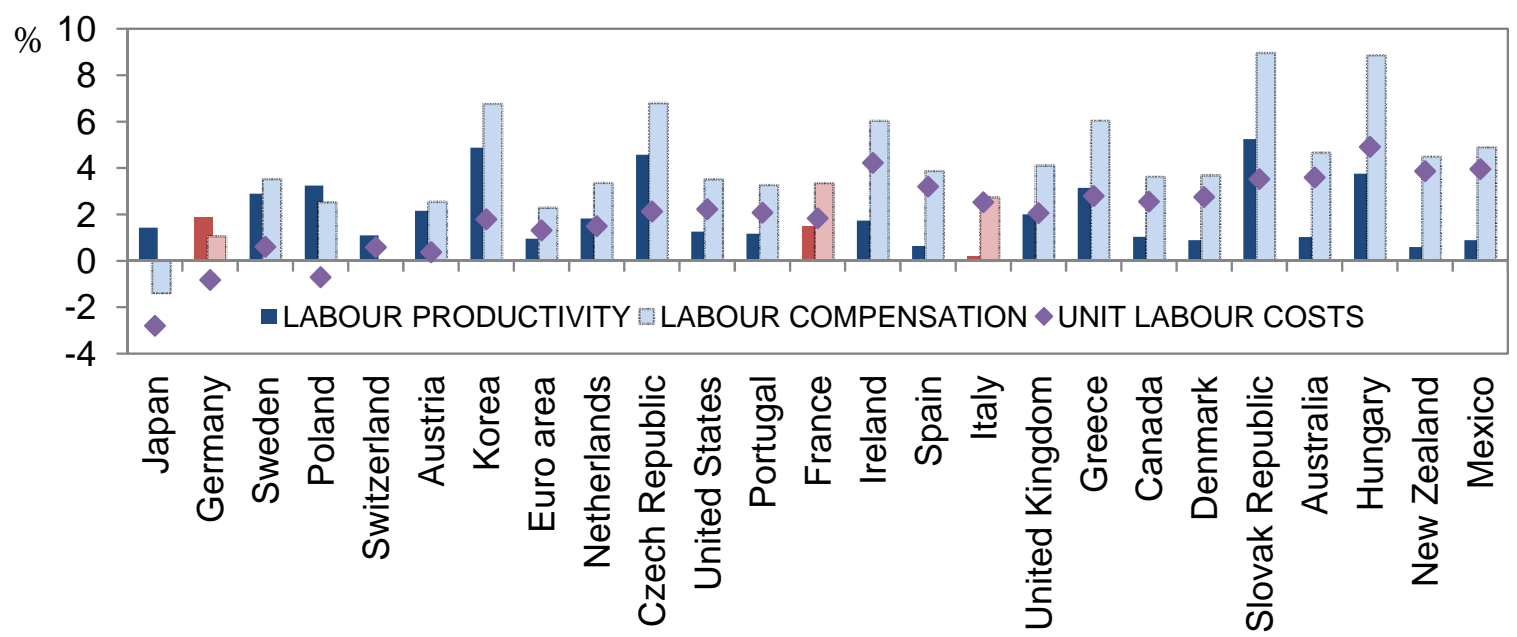

C. $2007-2011$

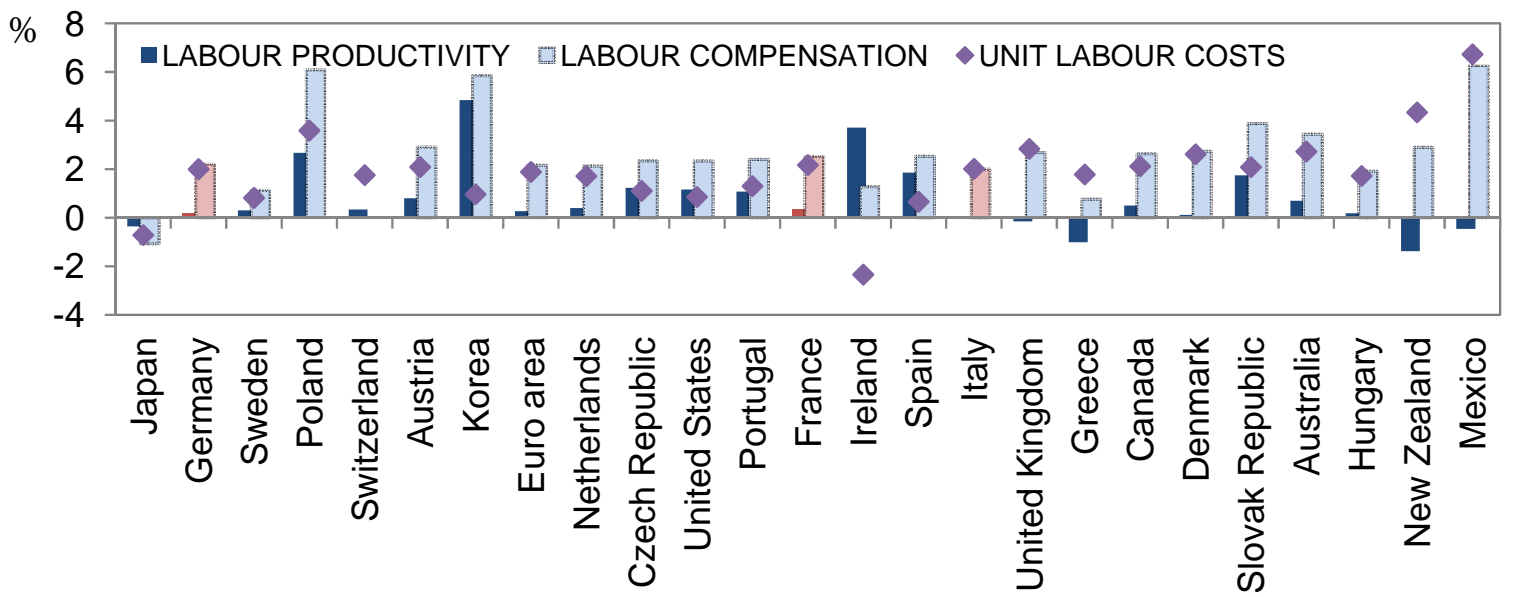

Note : Countries are ranked according to the period 2001-2011. Information on total hours worked is not available for all countries in all periods and so proxies, such as employees or the numbers of persons employed are used instead. This means that the labour productivity estimates shown above are not necessarily identical to those sourced from the OECD Productivity Database.

Source : OECD Labour Costs Database, October 2012 
Figure 12. Real effective exchange rate

$\%$

Cumulated percentage change, 2000-2011

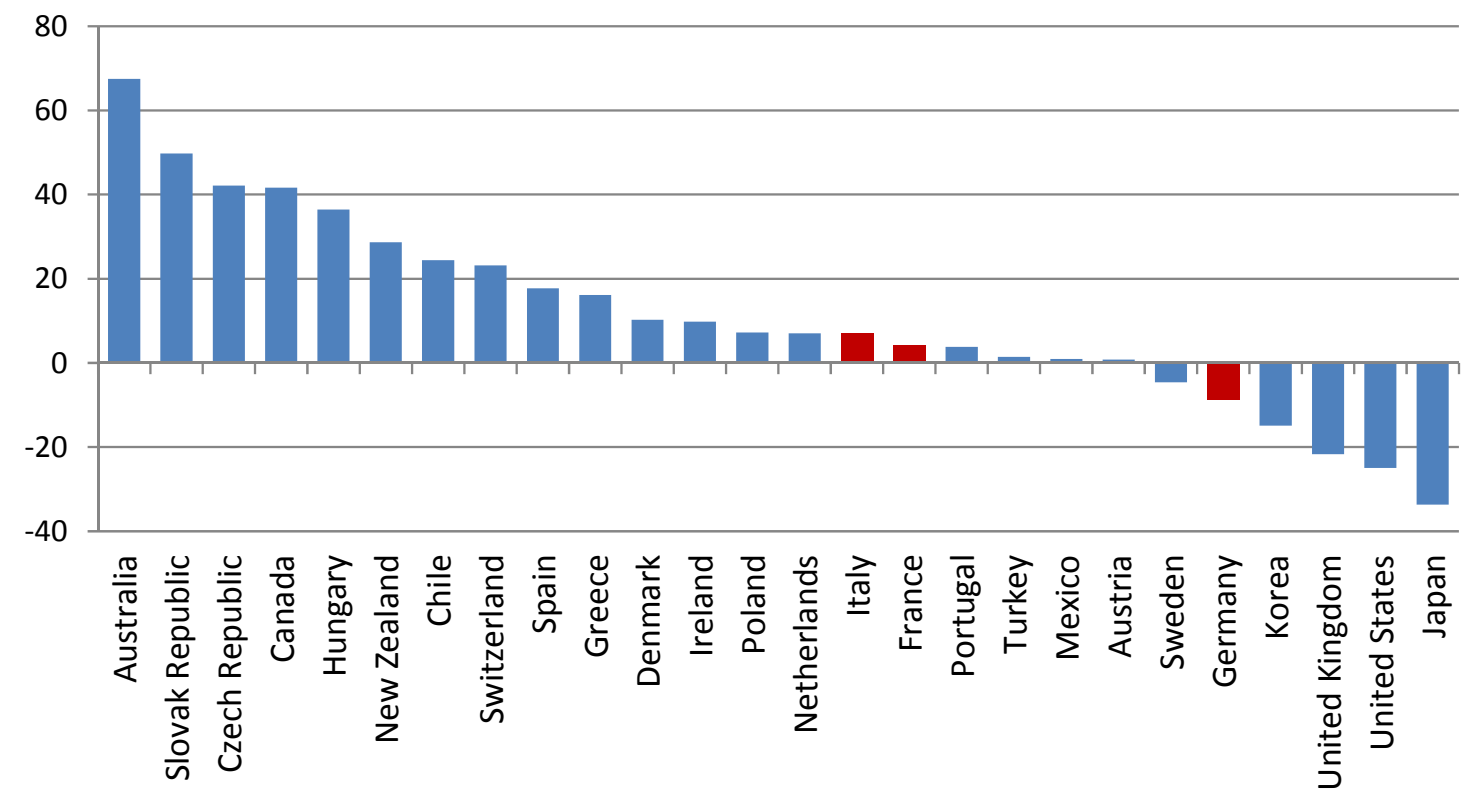

Source : Economic Outlook 91 (May 2012) Database.

Outside the euro area, unit labour costs have also increased but from lower absolute levels (Mexico, eastern European countries) or have been compensated by depreciating exchange rates (eg United States, United Kingdom). 


\section{Losses in trade market shares}

Over the past decade most advanced OECD countries have been losing export market share to emerging-market countries, which have experienced strong productivity gains while keeping competitive wages. Losses in export market shares have been especially large for the euro area countries. Germany has been the only country with gains in international market shares (Figure 13). The Eastern European countries (either within or outside the euro area) have shown considerably larger market gains than Germany, reflecting the opening of these economies, combined with a business friendly environment, low cost levels, and large incoming FDI.

\section{Figure 13. Export performance}

Cumulated gains or losses in market share, percentage change, 2000-2011

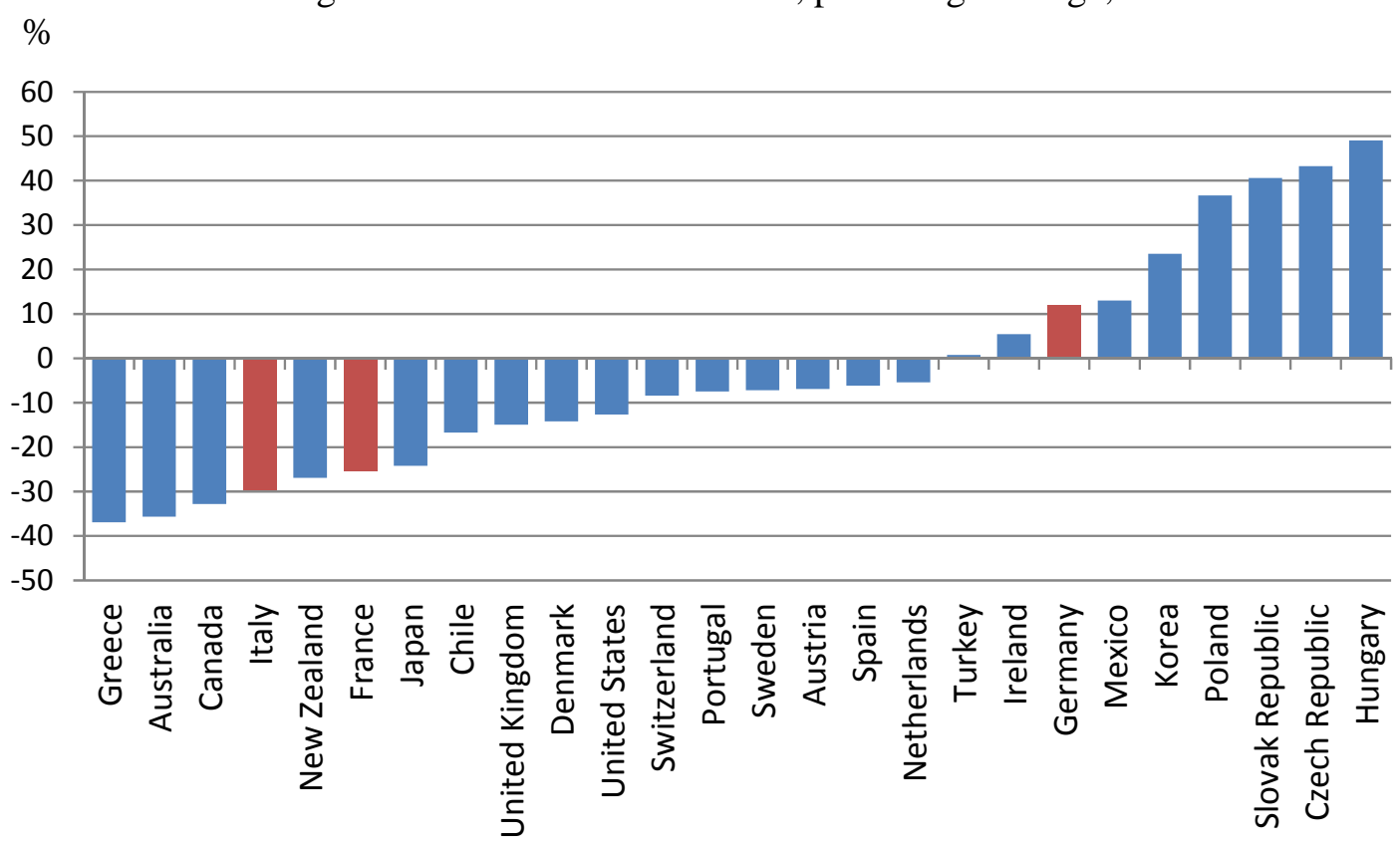

Note : Export performance measures the relative gain and losses of world market share of a given country. If a country's exports are growing faster (slower) that the weighted average demand from its partners, it is gaining (loosing) market share.

Source : Economic Outlook 91 (May 2012) Database. 


\section{Long-term prospects point to a weaker performance}

\section{Ageing will weigh on potential employment}

Going forward, several euro area countries will be faced by a very rapid ageing of their population (Figure 14). This is particularly true in Italy and Germany where the ratio of the working population to the population above 65 will decline from 5 and 4 respectively to less than 2 in 2050.

Figure 14. Old age dependency ratios

Working age population (20-64) per Retirement age population (65+)

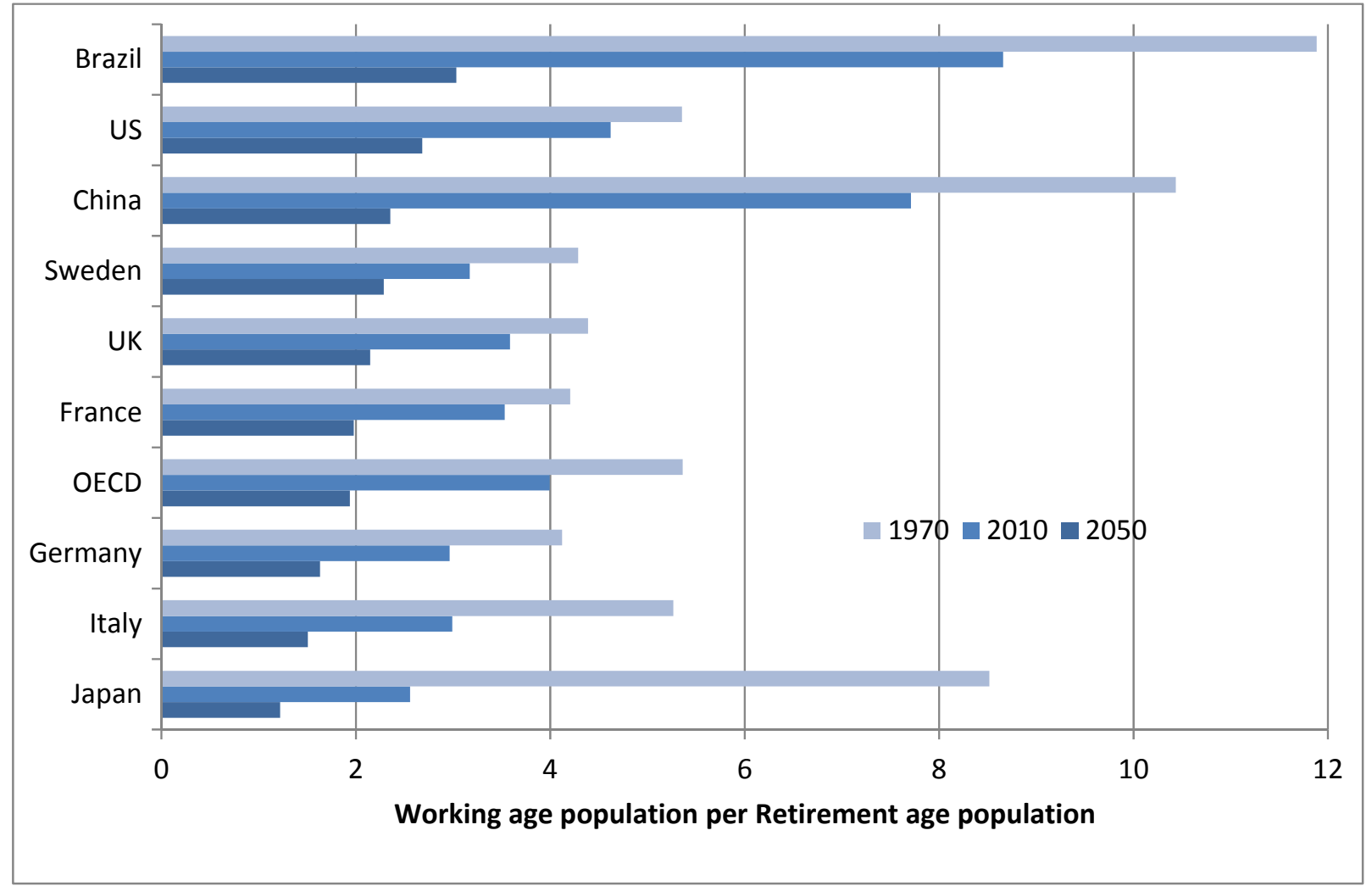

This will lead to negative potential employment growth (Figure 15 panel B). If productivity gains remain comparatively modest, the growth performance in the medium term for most euro area countries will be very weak. (Figure 15, panels A and C). This underlines the need for all euro area countries to continue efforts to boost productivity. 


\section{Long-term growth of potential output and its two sub-components}

Figure 15. Long-term growth, potential employment growth and potential labour productivity growth

Annual average of sub-periods, percentage change
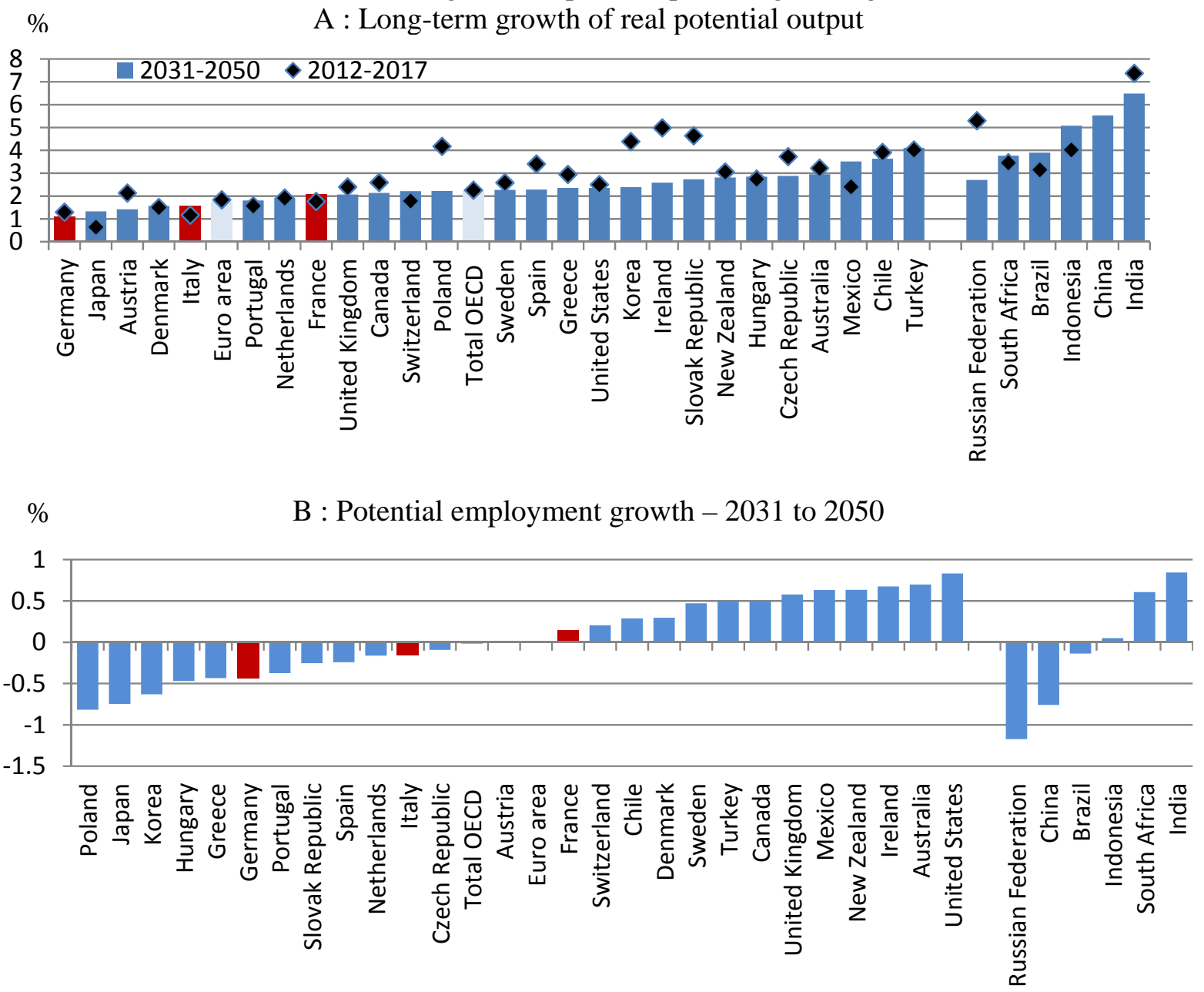

$\%$ C : Potential labour productivity growth -2031 to 2050

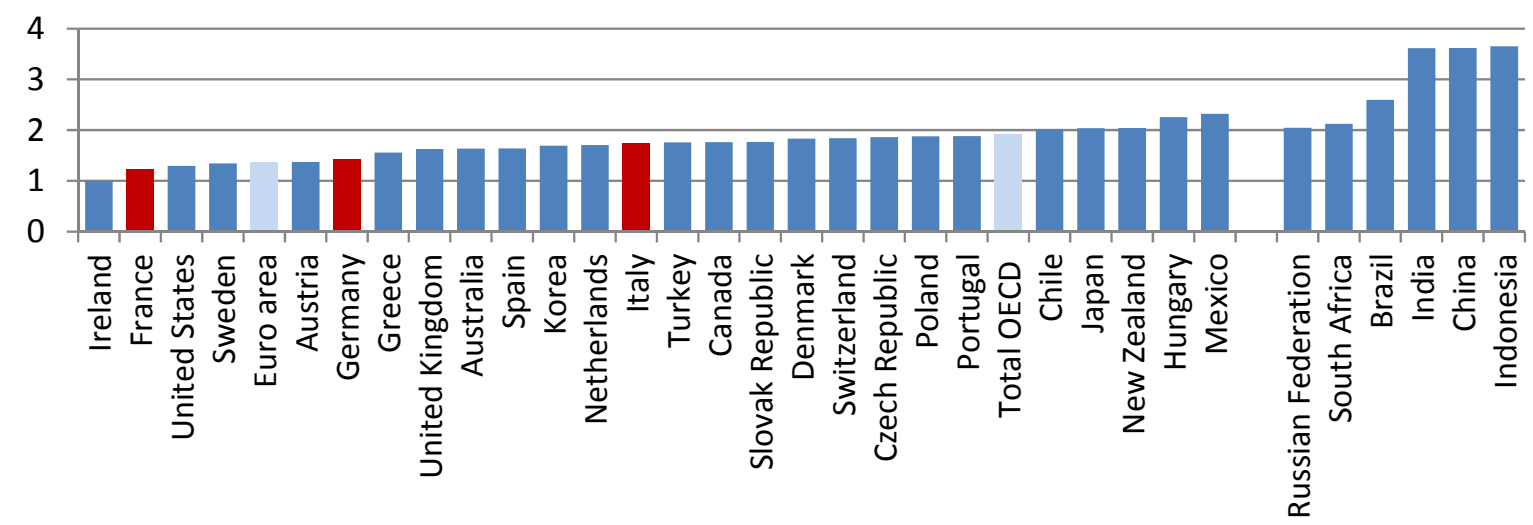

1. As a \% of mainland potential GDP.

Source : OECD Economic Outlook 91 (May 2012) long-term database. 


\section{Restoring competitiveness and addressing imbalances in the euro area}

The poor or insufficient productivity performance in most euro area countries over the past decade and the challenges of coping with population ageing calls for stronger productivity gains going forward, including in Germany, despite its strong performance in many areas. As long as the gains are wider in southern European countries this should also contribute to a reduction of imbalances within the whole euro area.

Previous OECD work has identified a number of reforms where policy changes could boost productivity: they include innovation, regulation of labour and product markets, taxation, and investment in skills and education. The relative position of the euro area countries on this broad range of policy dimensions are detailed in the following section.

All euro area countries have to make efforts in these areas. Precise recommendations need, however, to be adapted to each country's specific circumstances. Wide ranging reforms already taking place in Spain and Italy and being considered in France are going in the right direction, but need to be implemented and continued. The indicators presented below may not yet fully capture the recent efforts carried out in high reforming countries like Spain, Italy, etc.

Competitiveness also depends on a wide range of non-cost factors including products' variety and quality, technological innovation, specialisation and integration in global supply chains. These nonprice factors are driven by structural features, notably the development of human capital, the business environment and innovation policies which also drive productivity.

Wage compensation can also contribute to narrowing imbalances in the euro area and support competitiveness of the zone as a whole. In the short term this requires not only moderation in deficit countries, but also further wages catch up with past productivity gains in Germany. More fundamentally it calls for mechanisms allowing for a stronger link between productivity gains and wages. 


\section{Supporting innovation and knowledge based capital}

Innovation plays a key role for productivity enhancement. With some non-OECD economies accounting for a growing share of global $R \& D$, stepping up innovation is crucial for boosting Europe's competitiveness and achieving sustainable growth in the longer term. This is a particular challenge in Southern European countries, whereas Germany and Austria remain very well positioned and ahead of other euro area countries. With 2.8\% of GDP spent on R\&D, Germany accounts for almost $30 \%$ of EU27's total R\&D (Figure 16).

Business R\&D intensity is insufficient in most euro area countries, including France and Italy. On In 2011 business R\&D spending (BERD) in Germany was 1.92\% of GDP, well above the OECD and the EU27 averages, thanks to an economic structure highly skewed towards manufacturing and high tech sectors. There is however a bias in this support for export oriented manufacturing and in favour of incremental innovations of existing products and processes within existing firms. This may harm the adaptability of the German innovation system and businesses to further changes in international demand and notably the development of services going forward.

Figure 16. R\&D in OECD and non-OECD countries, 2009

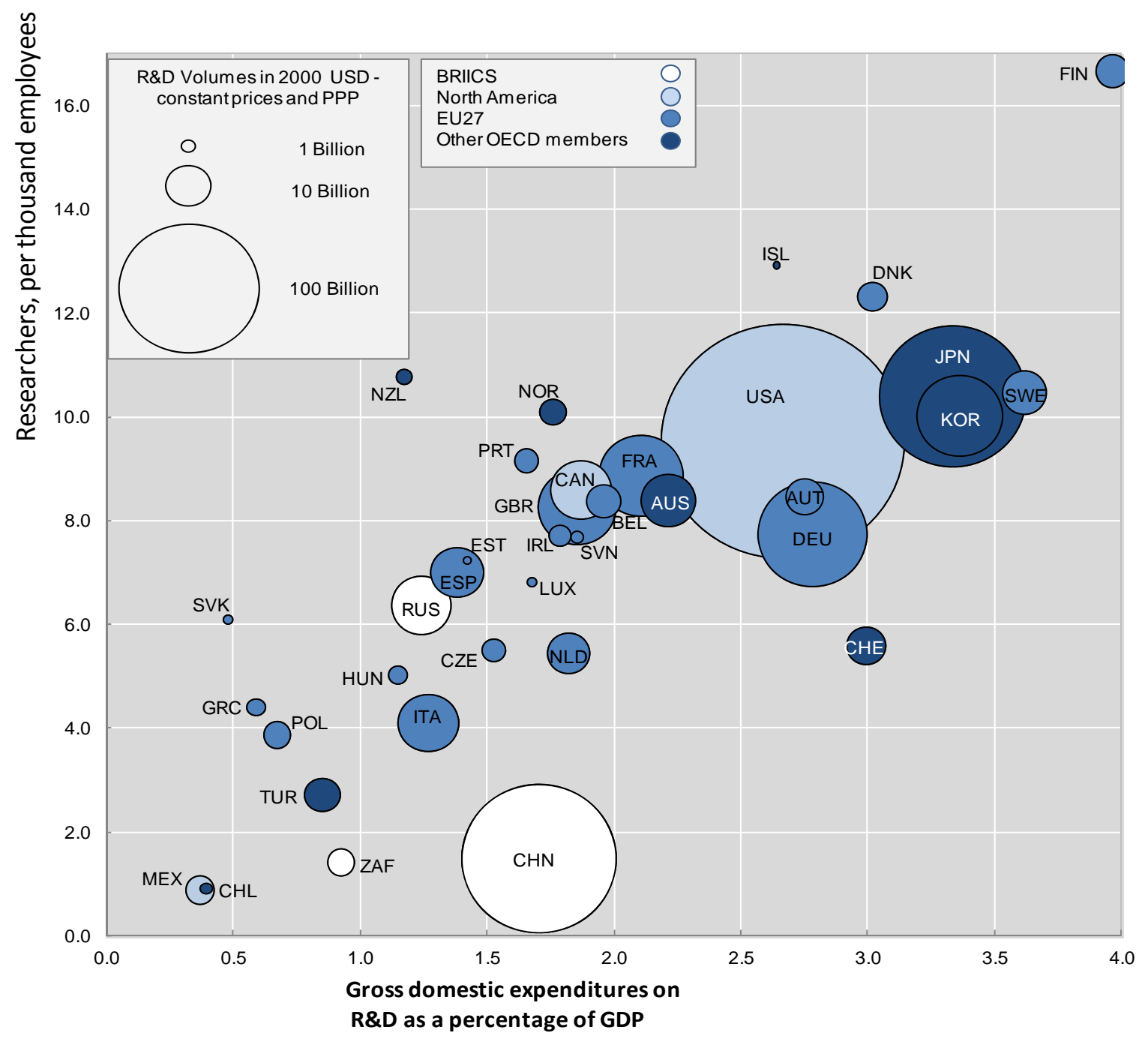

Source: OECD, STI Scoreboard 2011, based on Main Science and Technology Indicators Database, June 2011. 
Three types of knowledge based assets can be distinguished : computerised information (software and databases) ; innovative property (patents, copyrights, designs, trademarks); and economic competencies (including brand equity, firm-specific human capital, networks joining people and institutions, and organisational know-how that increases enterprise efficiency). The shift to investment in knowledge-based assets from 1995 to 2009 is a striking trend across all advanced economies. European countries still show a lower propensity to invest in these assets than the United States. The only exception is the UK whose propensity to invest in KBC is the highest in Europe, and which, like the United States, invests more in knowledge-based assets than it does in physical capital such as machinery, equipment and buildings (ie tangible assets) (Figure 17).

Further supporting innovation will require targeted policies (which depend on each country's specific position and strengths and weaknesses in this area ${ }^{2}$ ) but also improvement of the broader framework conditions, including the business environment and human capital.

Figure 17. Investment in fixed and intangible assets, 2009

as a percentage of GDP

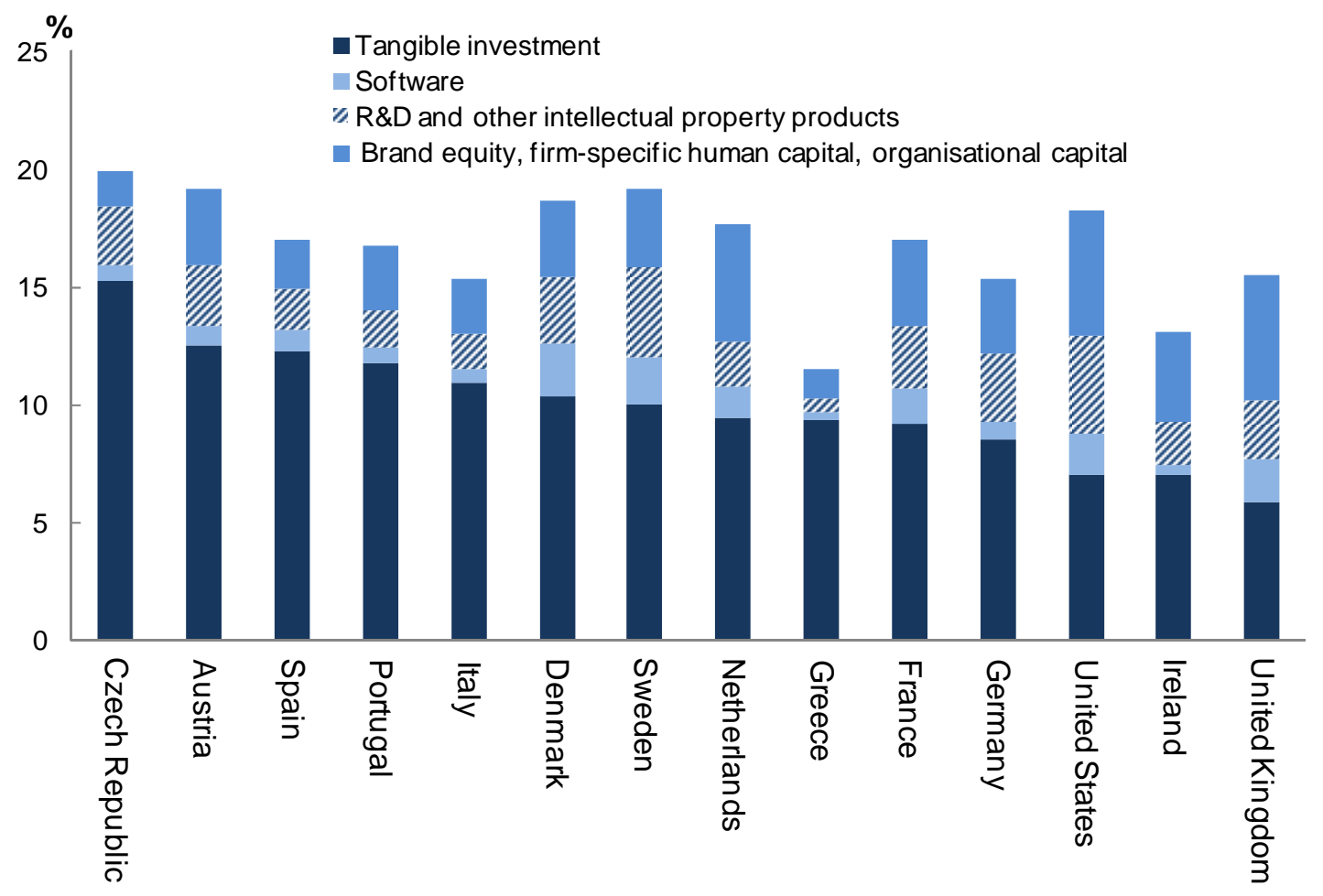

Source : Corrado, C., J. Haskel, C. Jona-Lasinio and M. Iommi (2012), "Intangible capital and growth in advanced economies : Measurement methods and comparative results", Imperial College Business School Discussion Papers, No. 2012/06

See OECD Science, Technology and Industry Outlook, 2012 


\section{Strengthening competition in product markets}

Increased product market competition is essential to support innovation and productivity. Furthermore, increased competition may affect the wage-bargaining process and increase the sensitivity of wages to productivity gains.

Several Southern euro area countries with strict product market regulation have implemented product market deregulation following the crisis. Even in countries where overall product market regulation is not restrictive compared to other OECD or euro area countries there is room for further action (Figure 18). For instance, while the overall restrictiveness of regulation is below the OECD average in Germany, Italy and Spain, the retail sector in these countries and the professional services sector in Germany and Italy are characterised by strict regulation (Figure 19). Germany has undertaken piecemeal action to lower barriers for entrepreneurship in professional services (notably a simplification and adjustment of architects' fees regulation), but other countries with very strict regulation of professional services, like Italy, have launched more ambitious reforms. Reforms in these areas could help foster a greater reliance on domestic demand in Germany by unlocking opportunities for investment and consumption in the service sector, and thereby contributing to the reduction of imbalances in the euro area.

Figure 18. Restrictiveness of economy-wide product market regulation

Index $\quad$ (Index scale of 0-6 from least to most restrictive)

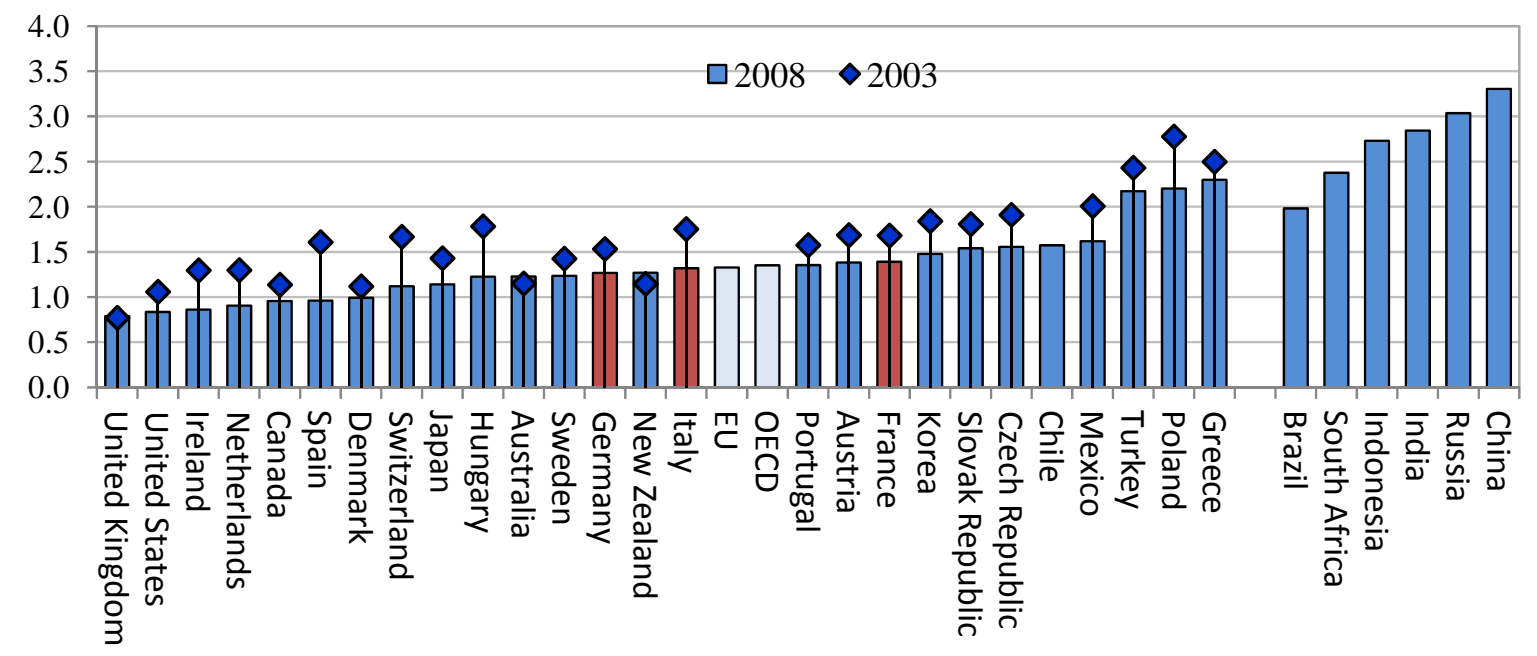

Note: The OECD Indicators of Product Market Regulation (PMR) are a comprehensive and internationally-comparable set of indicators that measure the degree to which policies promote or inhibit competition in areas of the product market where competition is viable. They measure the economy-wide regulatory and market environments in 30 OECD countries in (or around) 1998, 2003 and 2008, and in another 4 OECD countries (Chile, Estonia, Israel and Slovenia) as well as Brazil, China, India, Indonesia, Russia and South Africa around 2008 ; they are consistent across time and countries. Users of the data must be aware that they may no longer fully reflect the current situation in fast reforming countries.

1. This is a simple average of two indicators (regulatory and administrative opacity and administrative burdens on start-ups) in the domain "barriers to entrepreneurship".

Source : OECD (2011), Product Market Regulation Database and Woelfl, A. et al. (2010), "Product Market Regulation: Extending the analysis beyond OECD countries", OECD Economics Department Working Papers, No. 799. 
Figure 19. Sectoral regulation in retail and professional services

(Index scale of 0-6 from least to most restrictive)

A. Retail sector

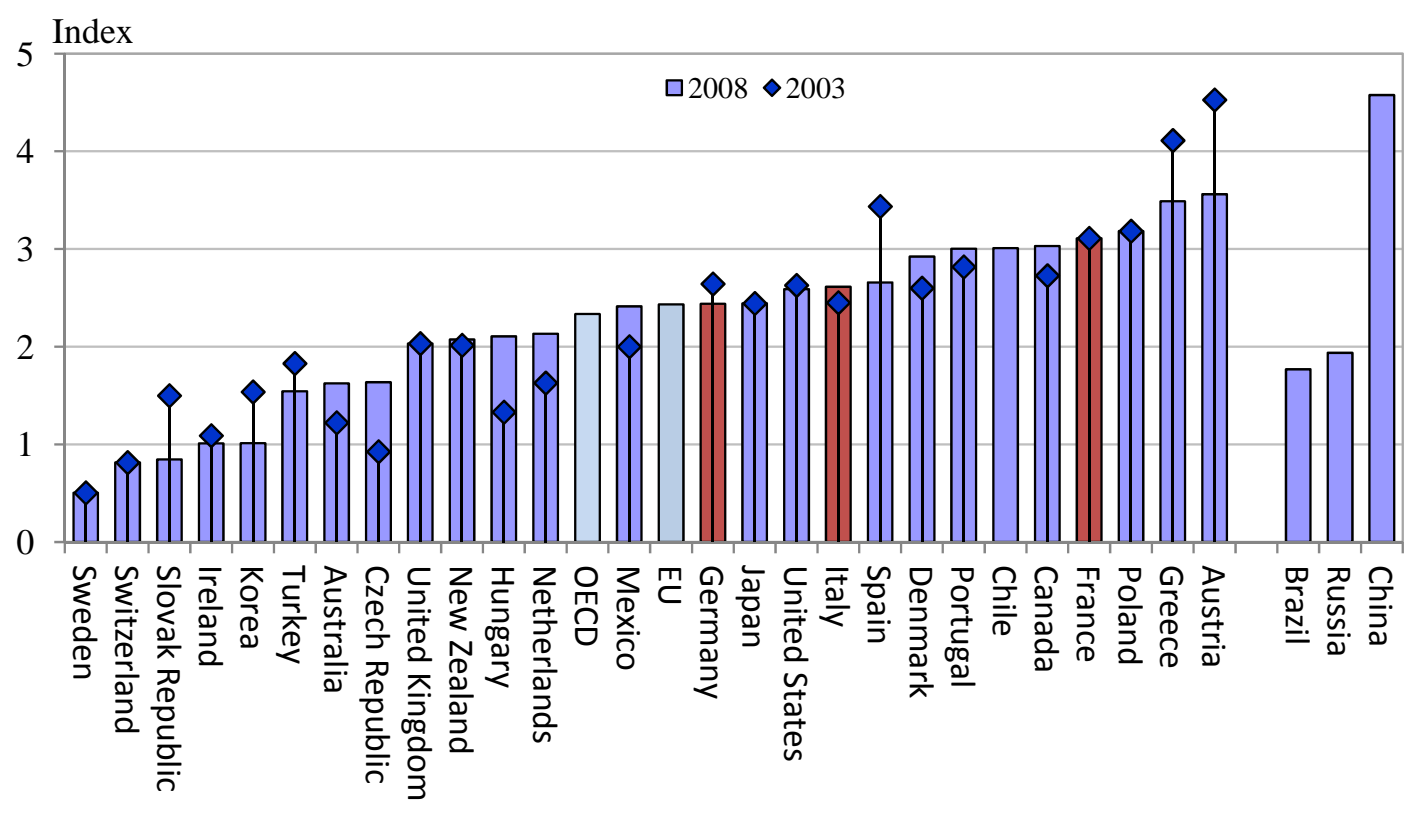

B. Professional services

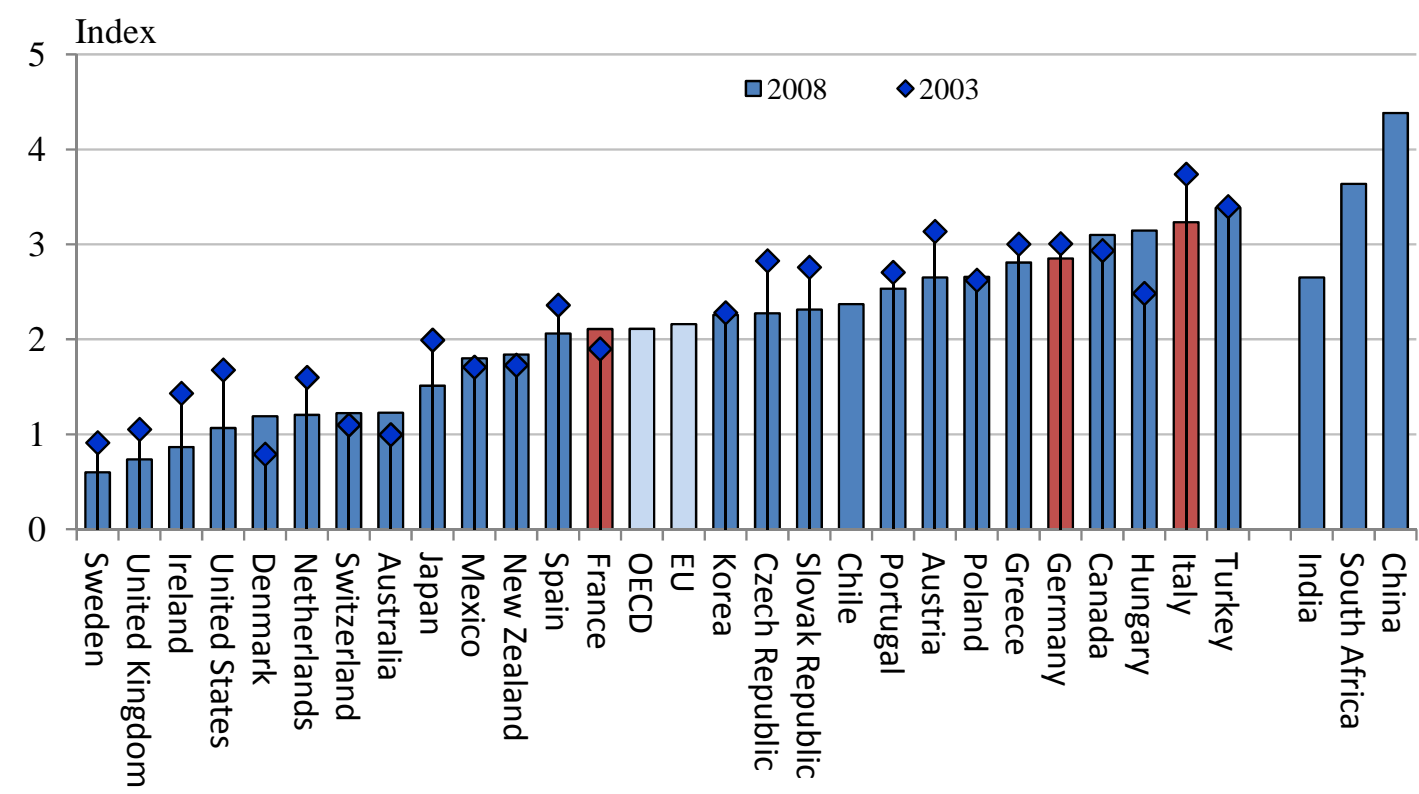

Note: The OECD cross-section sectoral indicators measure regulatory conditions in the professional services and retail distribution sectors. The retail indicators cover barriers to entry, operational restrictions, and price controls. The professional services indicators cover entry and conduct regulation in the legal, accounting, engineering, and architectural professions. Users of the data must be aware that they may no longer fully reflect the current situation in fast reforming countries.

Source : OECD (2011), Product Market Regulation Database. 


\section{Investing in human capital}

A highly skilled workforce is one of the main drivers of productivity and long-term growth. Education also plays a key role in reducing social inequalities.

Further improving the quality of secondary education remains a priority in many euro area countries, including Spain, France and Italy (Figures 20 and 21). It is also important that education systems, especially in France and Germany, play a larger role in promoting social mobility by providing all children with equal chances, independently of their social background (Figure 22).

While Germany's scores on educational attainment and achievements are comparatively high up to the level of secondary education, tertiary education remains a challenge. Despite progress, Germany scores relatively poorly on tertiary education (Figures 23 and 24). An estimated $42 \%$ of young people in Germany are expected to enter tertiary-type A programmes in their lifetime (OECD average : $62 \%$ ), and an estimated $30 \%$ of young people are expected to graduate from them (OECD average : 39\%). Moreover, an estimated $21 \%$ of young people in Germany are expected to enter tertiary-type B (vocationally oriented) programmes (OECD average : 17\%), and an estimated 14\% are expected to graduate from them (OECD average : 10\%). This reflects the still segmented school system, which does not encourage enough tertiary studies. Germany needs to step up efforts to prepare a large share of a cohort for tertiary studies by further reducing early tracking and streaming of students as well as increasing the permeability of its successful dual vocational training system. Furthermore, though progress has been made in recent years, it should allow all universities greater autonomy. Another challenge is to promote student's enrolment in science-related fields which would help support further innovation (Figure 25).

In most EU countries, extra-EU immigrants are predominantly low skilled in comparison with other parts of the OECD area that manage to attract relatively more high-skilled workers (Figure 26). A stronger EU-level migration policy can help ease future skill shortages. The European Blue Card, which offers extra-EU immigrants a scheme that grants free movement within the EU, is a step in the right direction. However, some EU countries have still not passed national legislation to make this possible. 
Figure 20. Graduation rates in upper secondary education

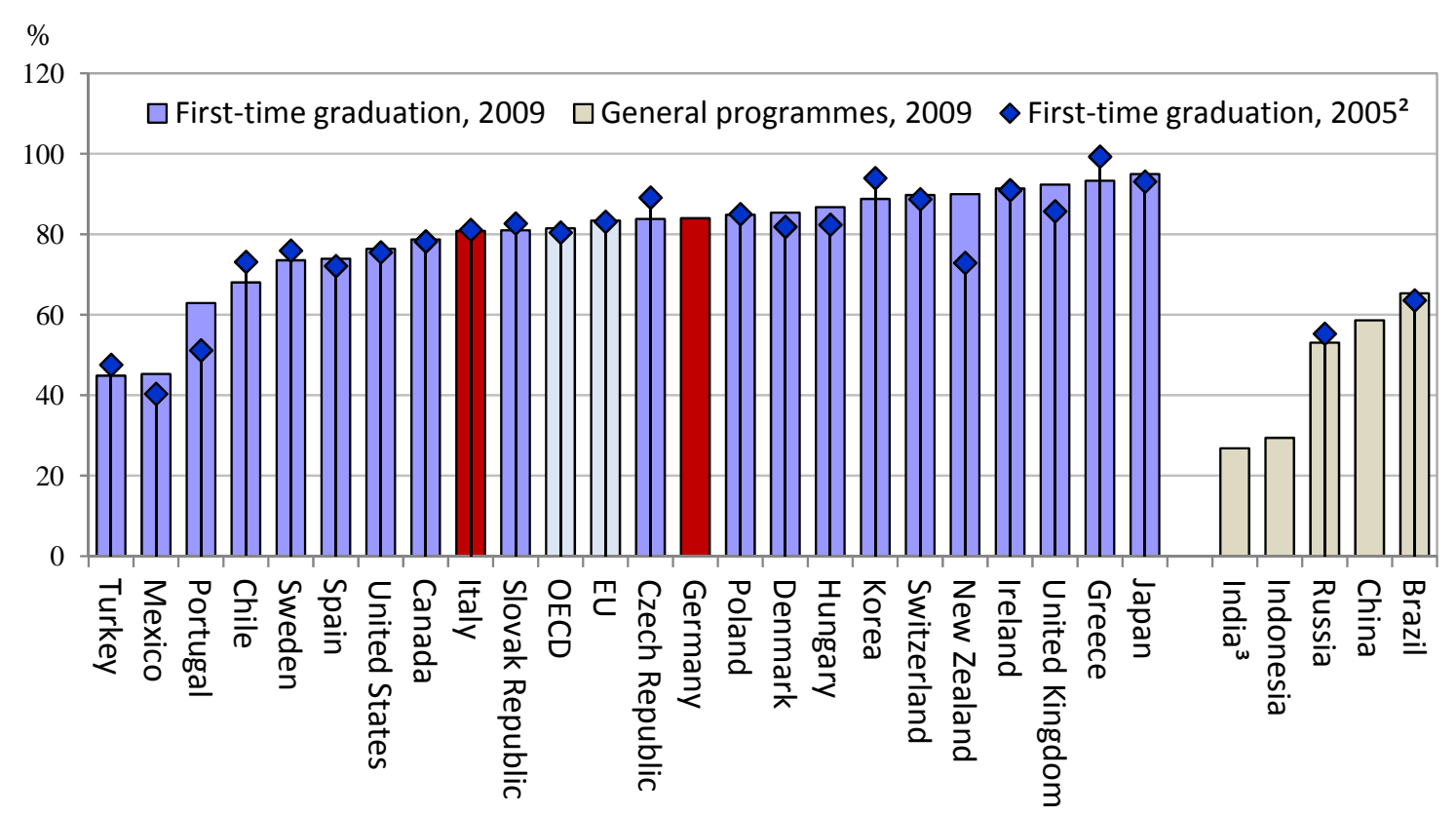

Note : Graduation in both general and vocational programmes, unless mentioned otherwise

1. Data refer to 2010 for China ; 2008 for Canada, Greece, India, Portugal and Switzerland

2. For Brazil and Russia, data for 2005 refer to general programmes. Comparable data does not exist for Germany due to a statistical break.

3. Data for upper secondary education in India are defined as 19 years-old who completed upper secondary education

Source: OECD (2011), Education at a Glance; China Statistical Yearbook and India National Sample Survey (2007/8).

Figure 21. Educational achievement :

Average of PISA scores in reading, mathematics and science

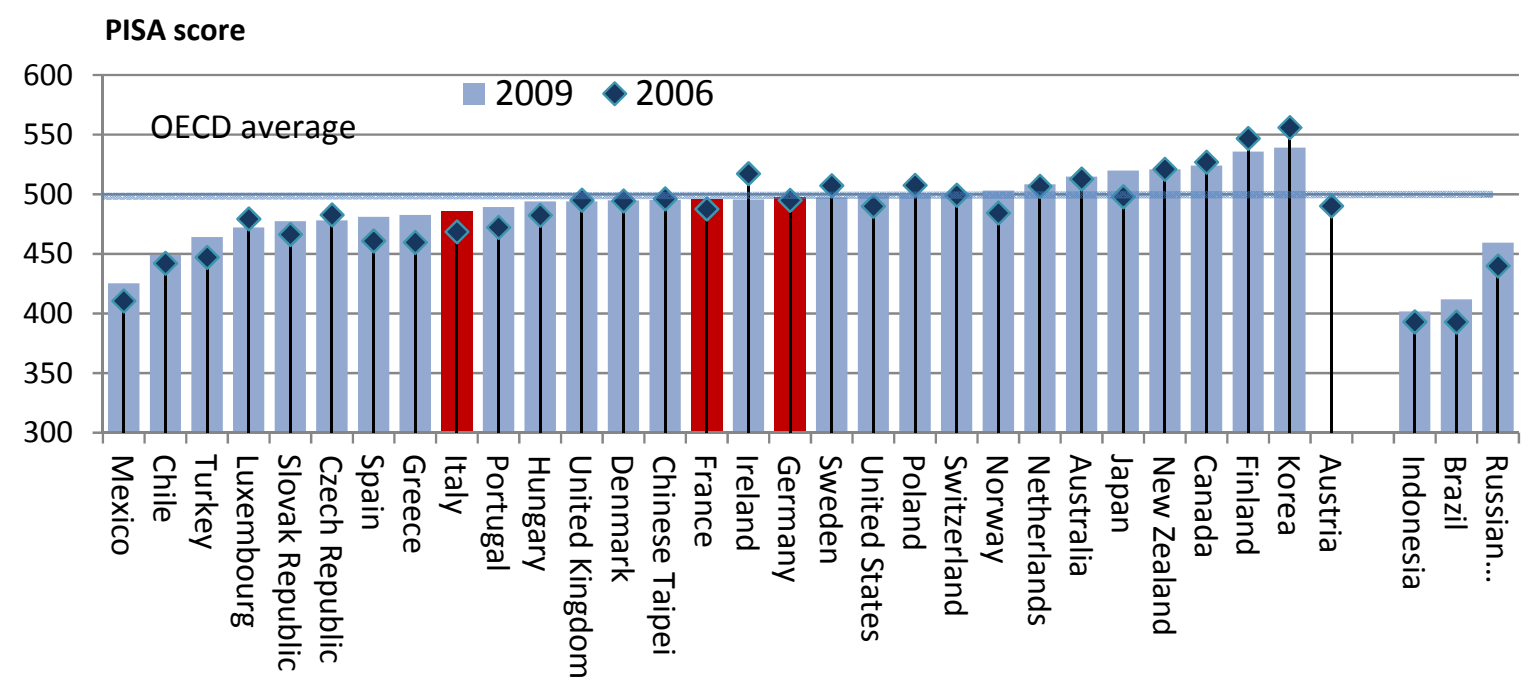

Source : OECD (2010), PISA 2009 Database. 
Figure 22. Impact of social background on pupils’ performance

$\checkmark$ Strength of the relationship between performance and socio-economic background above the OECD average impact

$\diamond$ Strength of the relationship between performance and socio-economic background not statistically significantly different from the OECD average impact

$\checkmark$ Strength of the relationship between performance and socio-economic background below the OECD average impact

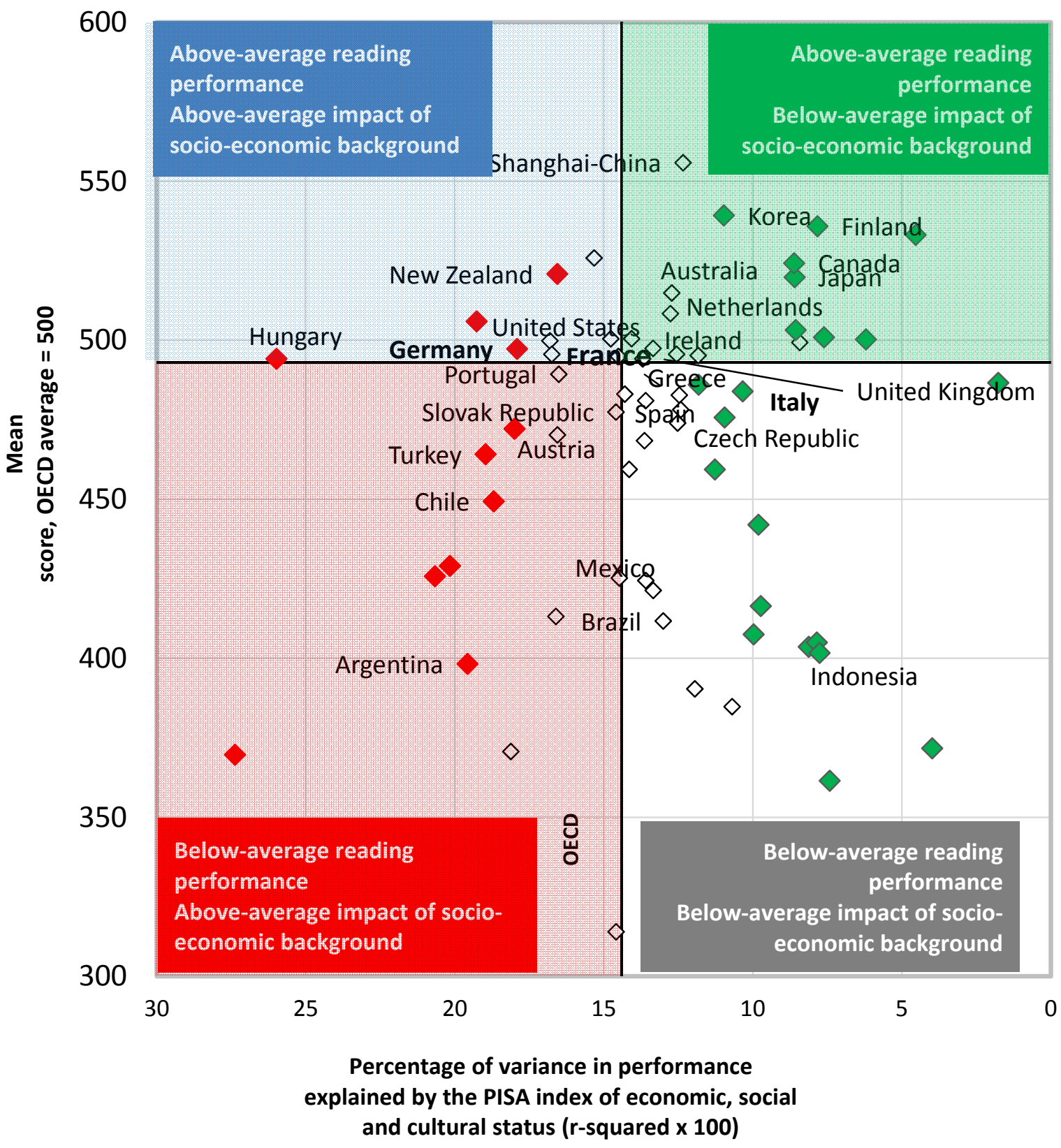


Figure 23. First-time graduation rates at tertiary-type A and B education (\%, 1995 and 2010)

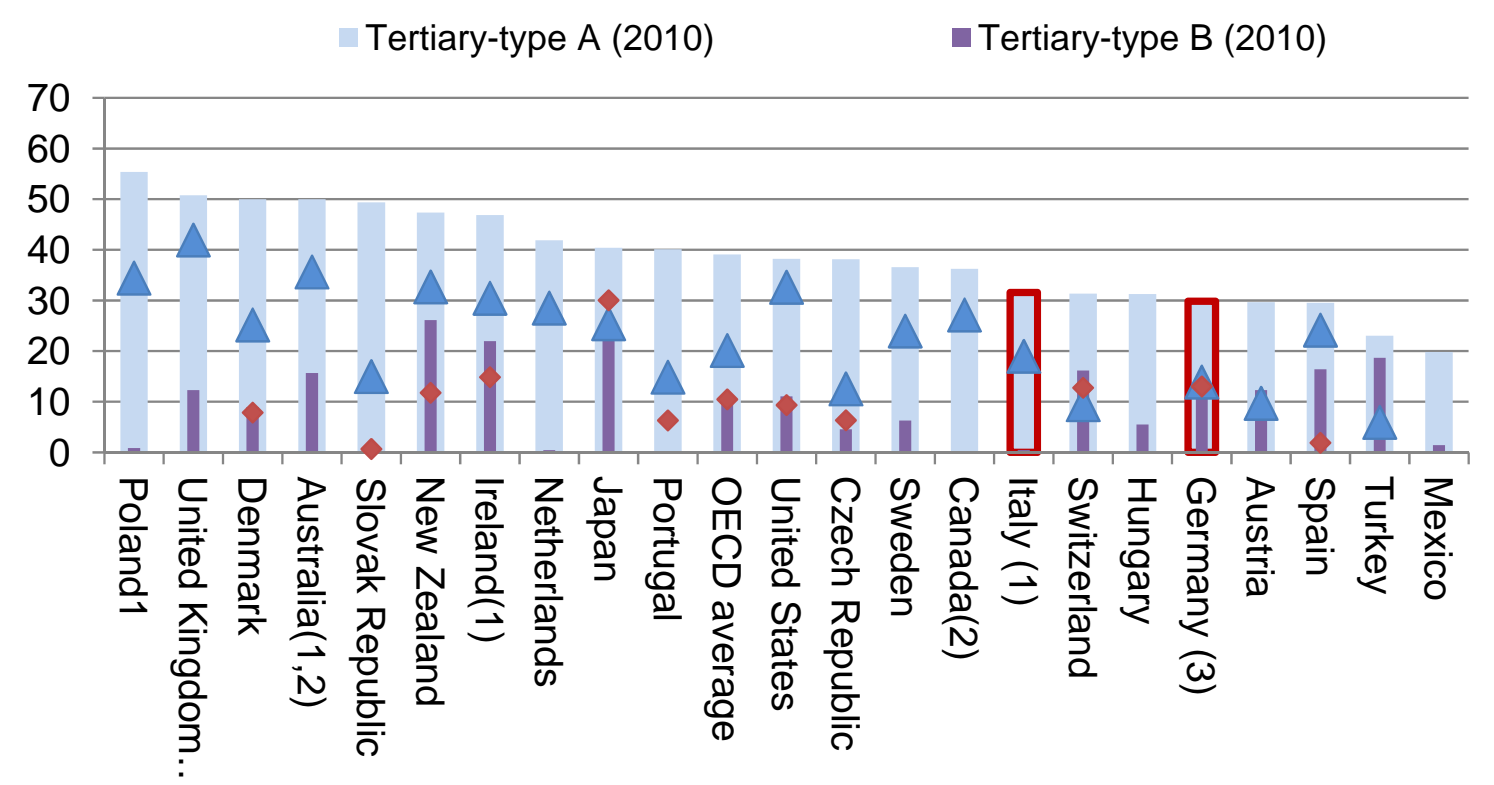

Note : Users of the data must be aware that they may no longer fully reflect the current situation in fast reforming countries.

1. Data refer to 2008 for Australia, Canada, and Greece.

2. $\quad$ For Brazil, Indonesia and Russia, data refer to first degree graduation in years 2006 and 2009.

3. Data for tertiary education refer to the 24 years-old and over who got graduated.

Source: OECD (2011), Education at a Glance; China Statistical Yearbook and India National Sample Survey (2007/8).

Figure 24. Population that has attained tertiary education (2010, or latest year available)

Percentage, by age group

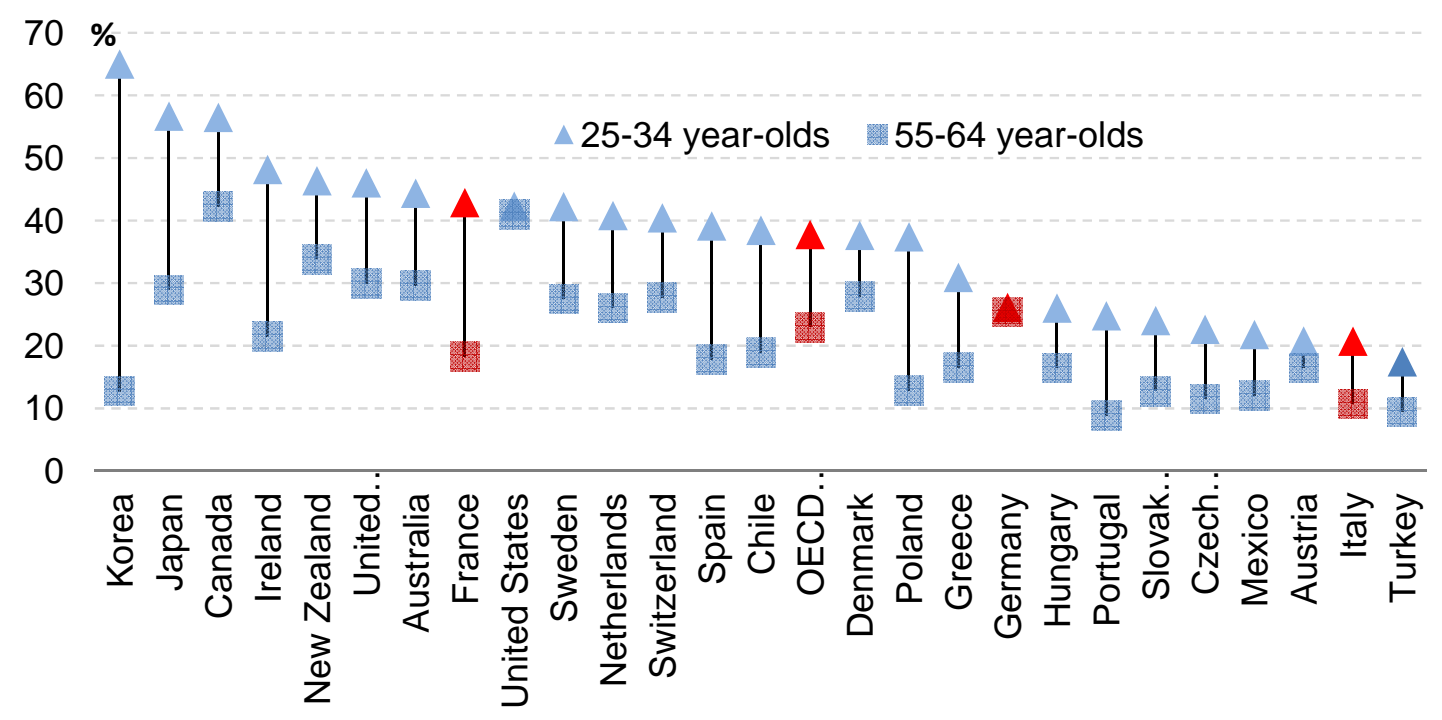

Source: OECD. Table A1.3a. See Annex 3 for notes (www.oecd.org/edu/eag2012). 
Figure 25. Tertiary graduates in science-related fields among

25-34 year-olds in employment, by gender (2009)

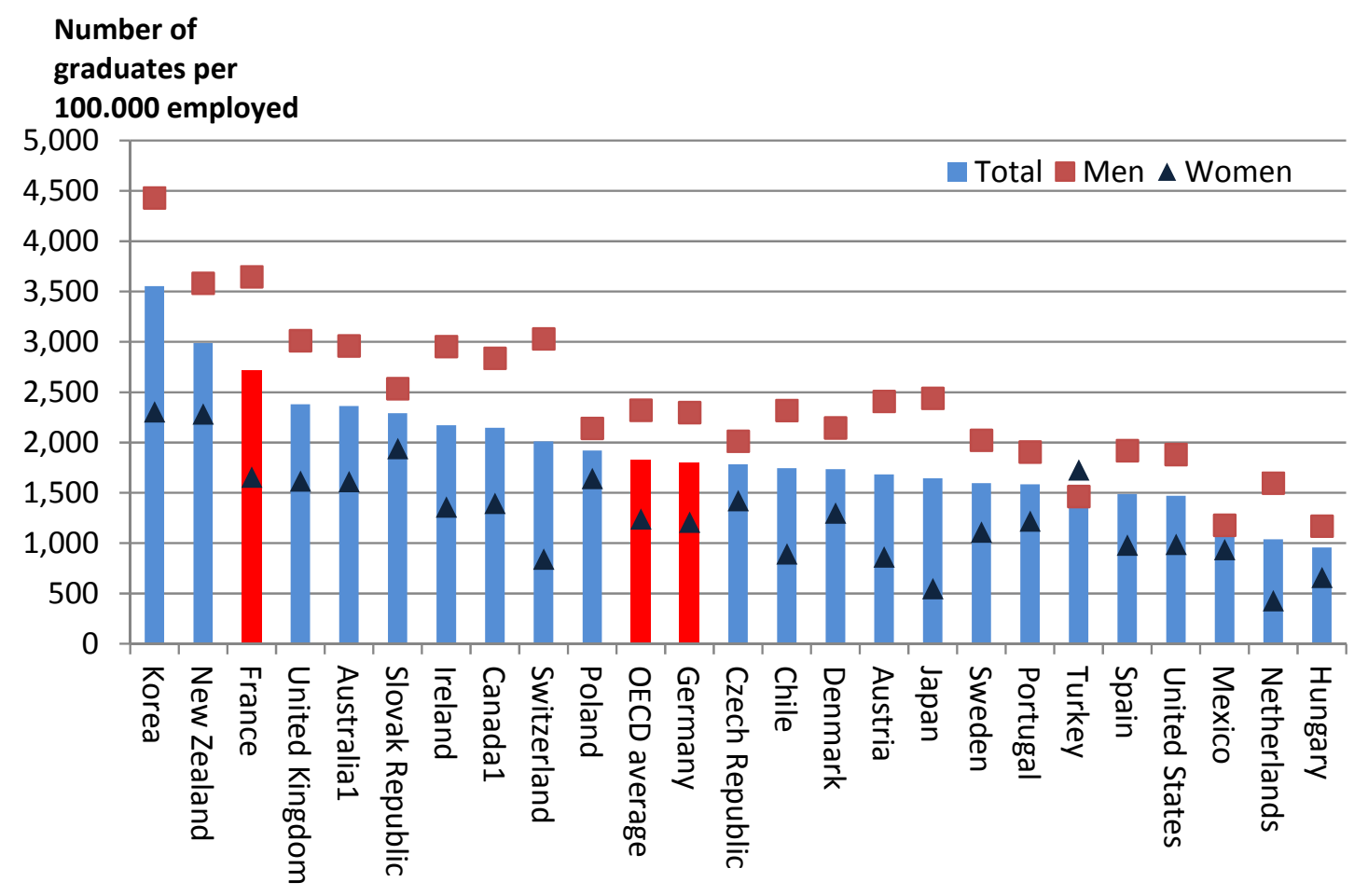

Note: Science-related fields include life sciences; physical sciences, mathematics and statistics, computing ; engineering and engineering trades, manufacturing and processing, architecture and building. Countries are ranked in descending order of the percentage of tertiary science-related graduates in tertiary-type A programmes per 100000 employed 25-34 year-olds.

1. Year of reference 2008 for the number of graduates.

Source : OECD. Table A4.6. See Annex 3 for notes (www.oecd.org/edu/eag2011). 
Figure 26. Immigrants by level of education

Share in the total born of foreign-born, 2005/06, \%

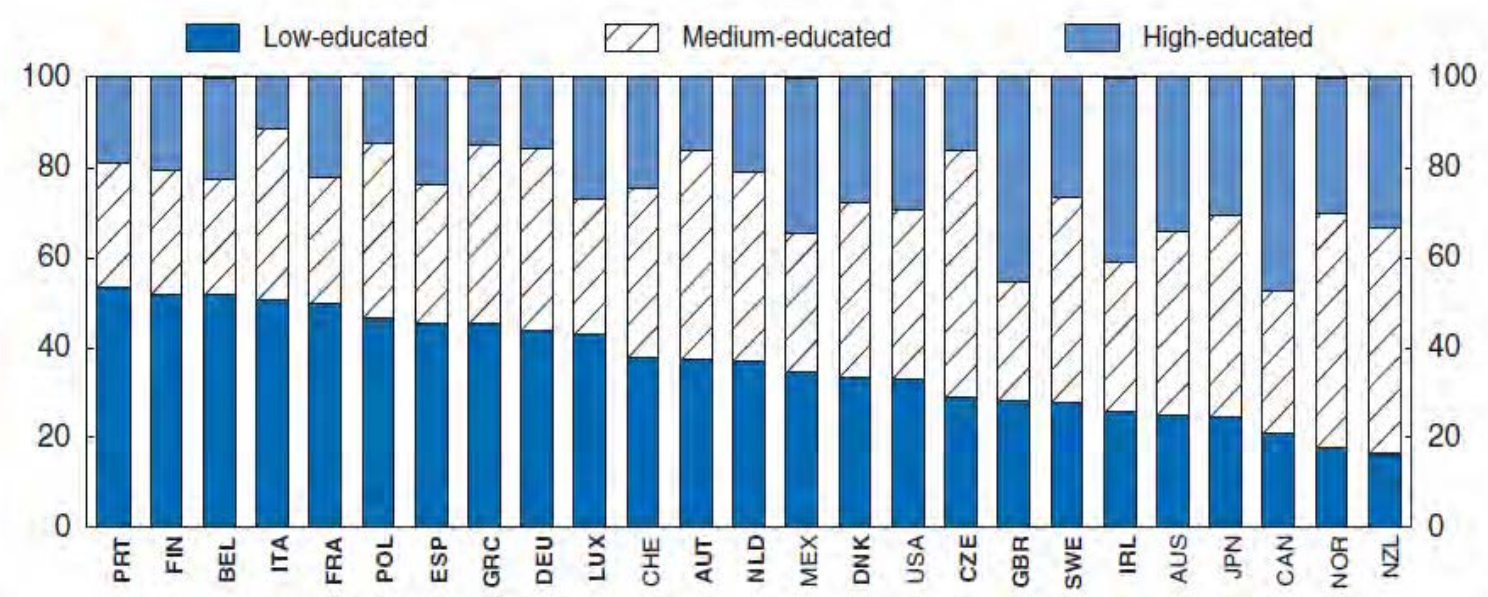

Source: Widmaier, S. and J.-C. Dumont (2011), "Are Recent Immigrants Different? A New Profile of Immigrants in the OECD based on DIOC 2005/06", OECD Social, Employment and Migration Working Papers, No. 126, OECD Publishing, Paris. 


\section{Improving the functioning of labour markets}

Labour markets play a central role in boosting productivity by channelling investment in human capital to its more effective use, and facilitating the adjustment of the economy in a changing world. They also have an important role in making growth more inclusive.

Many countries in Europe are faced with dualism in the labour market between the well protected workers on permanent contracts, and the less protected workers in temporary contracts who bear the brunt of labour market adjustment. This stems mainly from strict employment protection for regular employment, often combined with the lax protection for temporary employment (Figure 27). It is essential to unify job protection for all workers in Europe.

Further progress in wage setting mechanisms can also play an important supportive role in strengthening the responsiveness of wages to productivity. Experience in OECD countries suggests that decentralised wage bargaining can help wages to better reflect productivity gains. Several euro area countries have already taken measures in this direction, with a visible impact on wage settlements. Spain, Greece and Ireland have eased the conditions for firms to opt out from higherlevel collective bargaining agreements, and Ireland has reformed sectoral wage agreements. In Italy, the 2011 agreement promoting the so called second-tier (firm-level) wage bargaining has had little effect so far. 
Figure 27. Employment Protection Legislation (EPL)

Scale from 0 (least stringent) to 6 (most restrictive)

A. Protection for regular employment

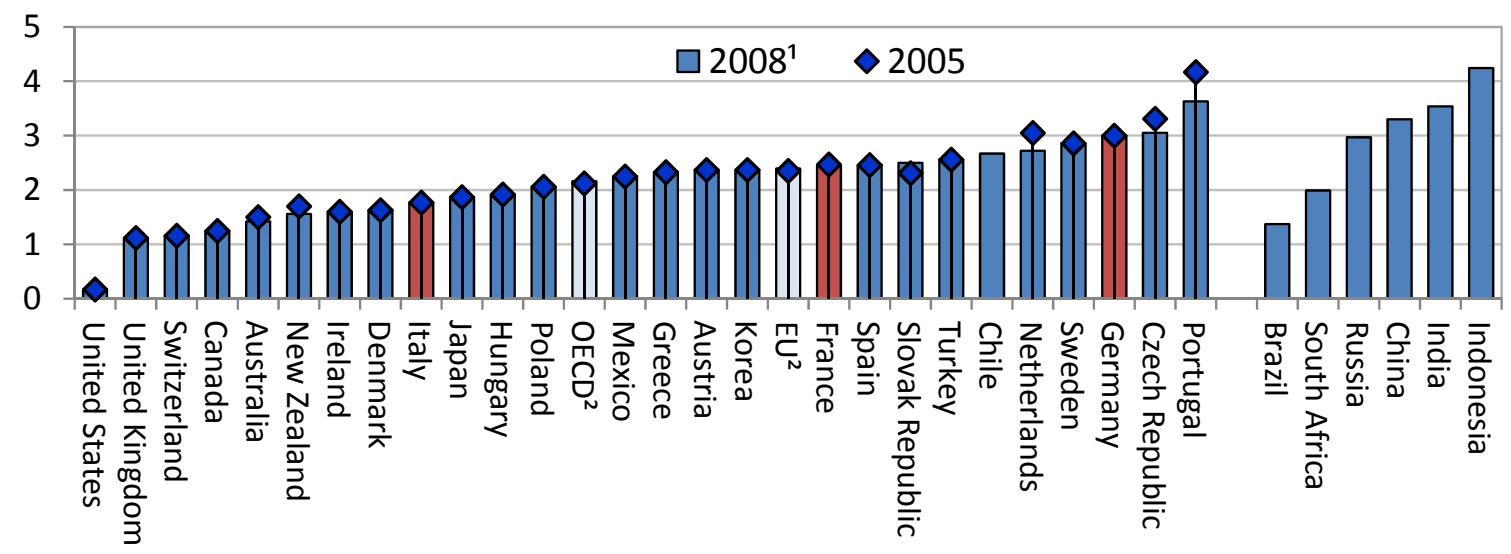

B. Protection for temporary employment

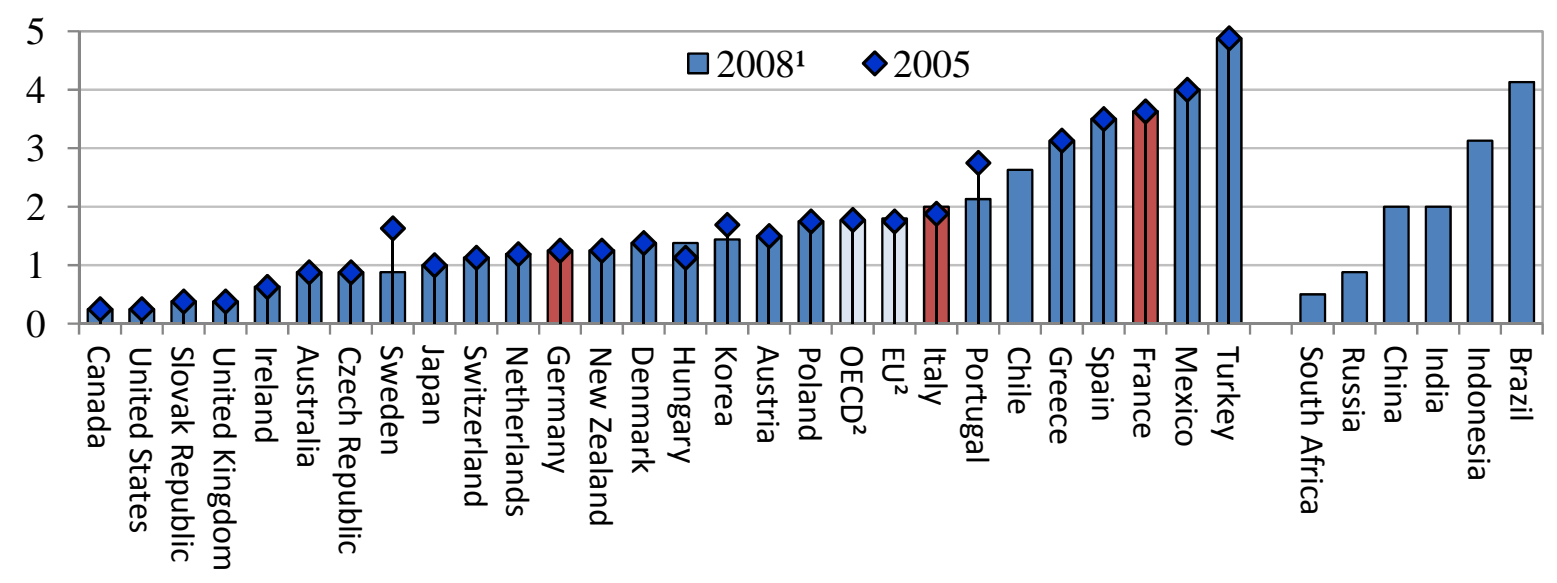

C. Additional protection on collective dismissals

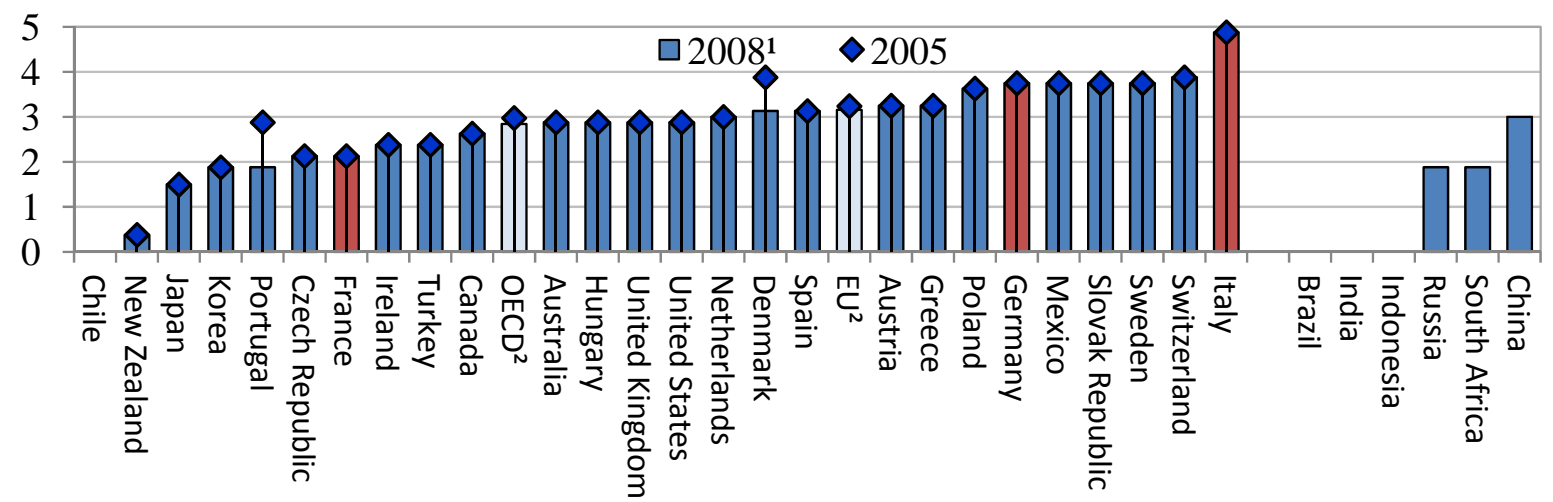

1. 2009 for France and Portugal. In panel C, values for Brazil, India and Indonesia are equal to zero in 2008.

2. In 2005, OECD and EU averages exclude Chile, Estonia, Iceland, Israel, Luxembourg and Slovenia.

Note: The OECD indicators of employment protection are synthetic indicators of the strictness of regulation on dismissals see www.oecd.org/employment/protection.

Source : OECD (2011), Employment Database. 
Figure 28. Coverage rates of collective bargaining agreements ${ }^{1}$

Per cent of all workers

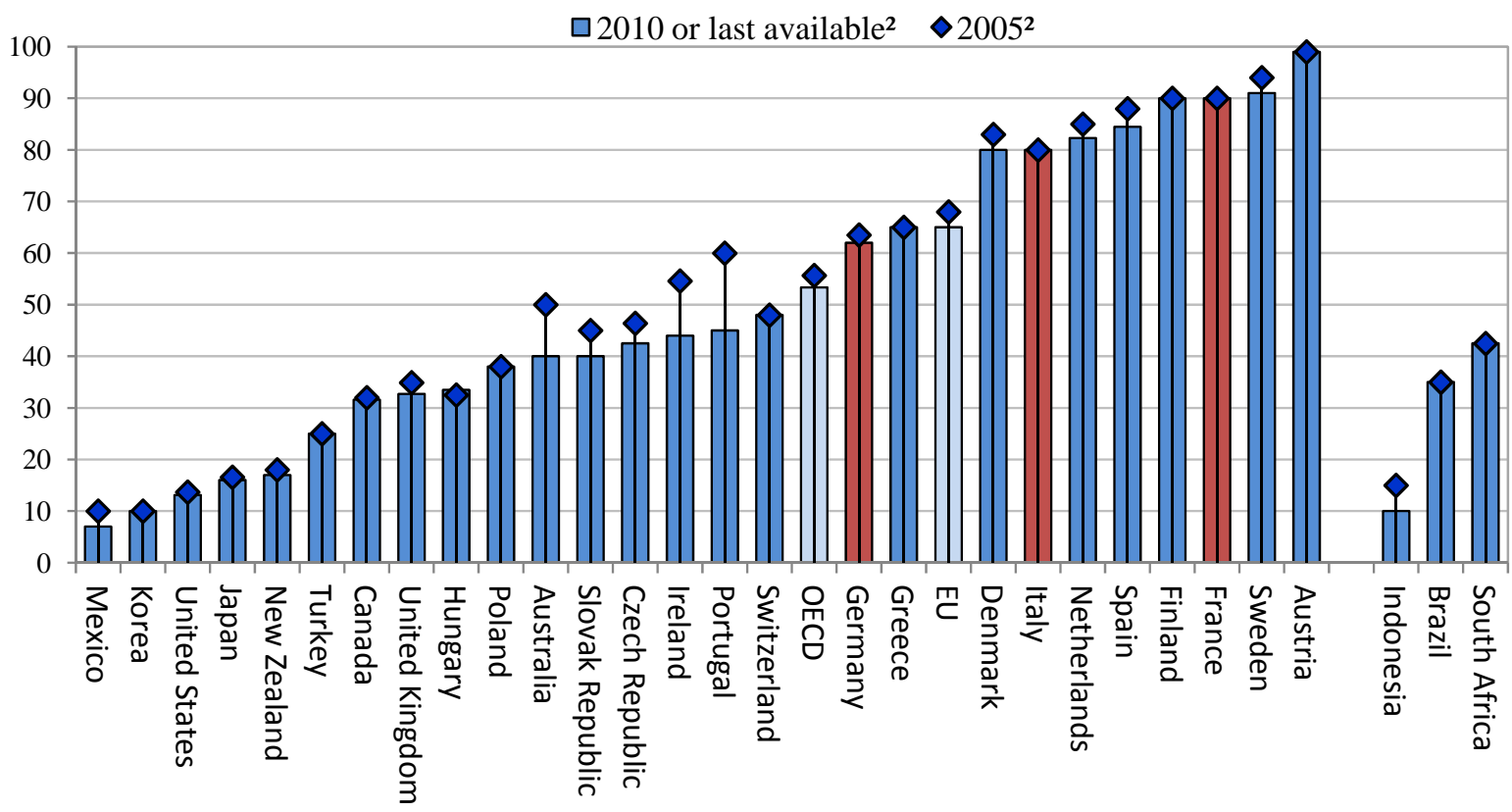

1. The coverage rate is measured as the percentage of workers who are covered by collective bargaining agreements, regardless of whether or not they belong to a trade union.

2. For 2010, the last available year is 2009 for Canada, Czech Republic, Estonia, Germany, Hungary, Italy, Portugal, Slovak Republic, and the United Kingdom ; 2008 for, Brazil, France, Greece, Indonesia, Ireland, Japan, Korea, Mexico, the Netherlands, Poland, South Africa, Spain, Sweden and Switzerland ; 2007 for Australia, Denmark, and New Zealand ; 2006 for Turkey. For 2005, data refer to 2006 for Korea, Switzerland and Slovak Republic ; 2004 for Spain ; 2003 for Brazil, Indonesia and New-Zealand ; 2002 for Austria, Denmark, France, Ireland, Mexico and Turkey; 2001 for Australia and Chile ;

Source : OECD estimates and J. Visser, Amsterdam Institute for Advanced Labour Studies (2011), ICTWSS Database on Institutions, Coordination, Trade Unions, Wage Setting and Social Pacts (version 3.0). 


\section{Reforming tax systems}

European countries are characterised by relatively high average and marginal tax wedges on labour (Figure 29). Another way to improve competitiveness is to reduce the tax wedge. In the current fiscal context, such measures have to be implemented in a "revenue-neutral" fashion. This can be achieved, for example, by reallocating the fiscal burden away from labour income onto taxation of property and environmental taxes.

Country specific issues also have to be addressed. For instance, in Germany and Italy, it is important to lower the tax wedge for second earners (which are among the highest in the OECD) in order to support women's participation in the labour market ${ }^{3}$.

In addition, the continuing downward trend in statutory corporate income tax rates suggests that many countries see lower rates as a way to promote domestic investment, including by making their economy more competitive as a location for FDI. The rates in France, Germany, Belgium and Portugal are among the highest in the OECD (Figure 30).

A reduction in the tax wedge and corporate tax rates could be achieved by a rebalancing of taxation towards indirect taxes and green taxes. A reduction in public spending in the countries where it is comparatively high, including in Germany, could also create room for such tax reductions. Indeed, in several countries, a high tax wedge and corporate tax rate correspond to high government expenditure as a share of GDP and high public employment in the labour force (Figure 31 and 32).

Figure 29. Marginal tax wedge on labour, at $100 \%$ of average worker earnings, single person without children

$\%$ Percentage of total labour compensation

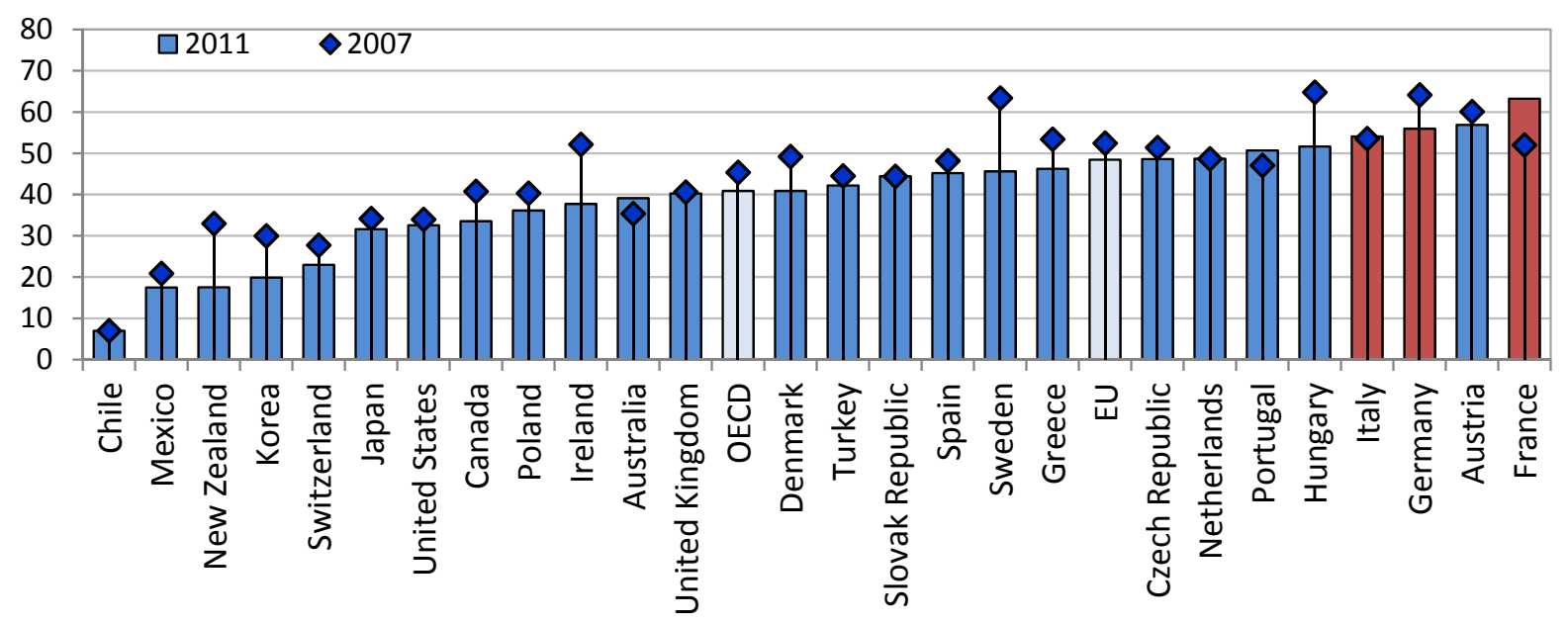

1. Measured as the difference between the change in total labour compensation paid by employers and the change in the net take-home pay of employees, as a result of an extra unit of national currency of labour income. The difference is expressed as a percentage of the change in total labour compensation.

2. $\quad$ Data refer to 2010 for Greece.

3. Wage figures are based on the old definition of average worker (ISIC D, rev3.).

Source : OECD (2012), Taxing Wages Database 
Figure 30. Statutory corporate income tax rates, 2012

(Combination (where appropriate) of both central and sub-central rates of tax)

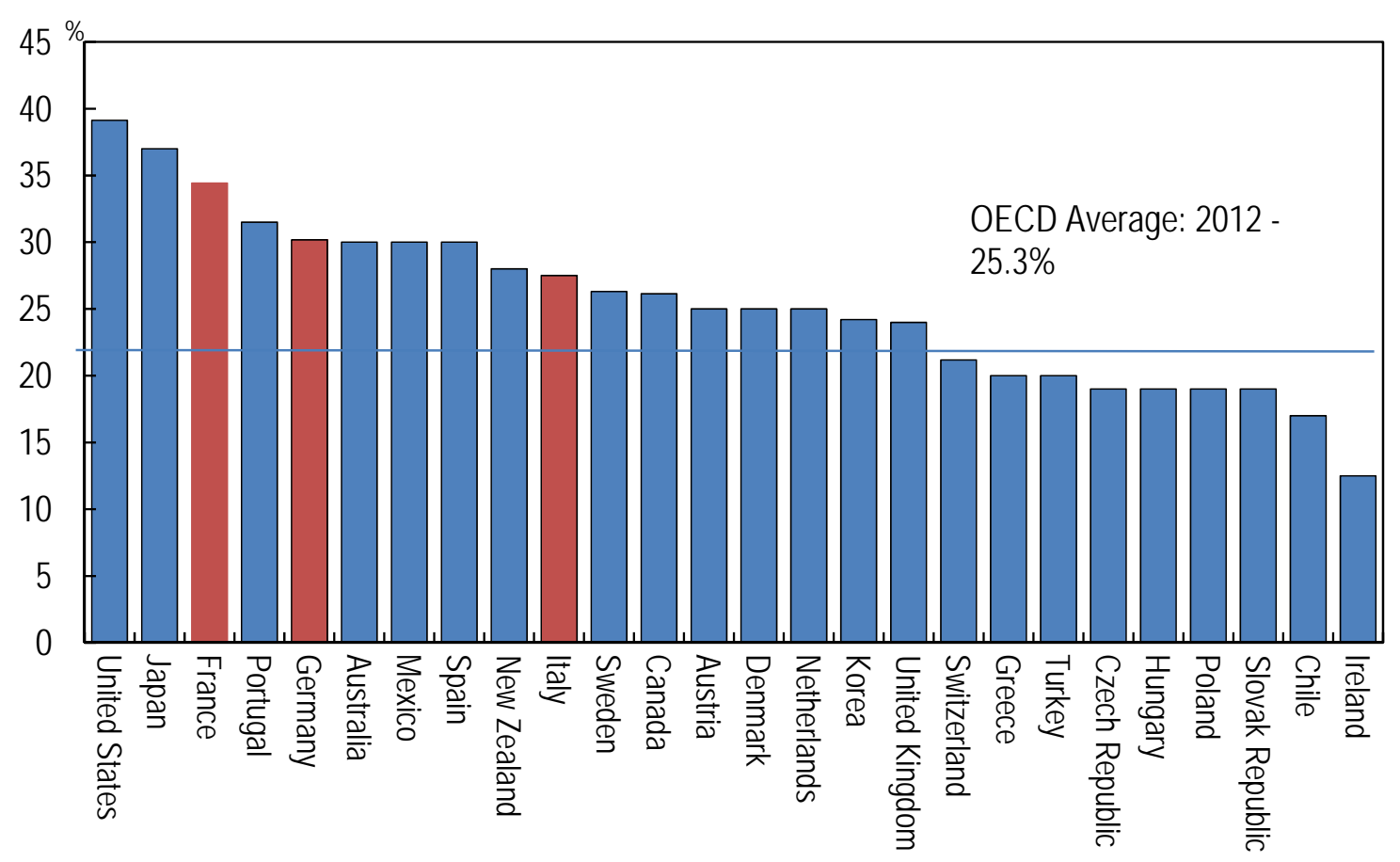

Source : OECD Tax Database Table II.1

Figure 31. General government expenditures as a percentage of GDP (2001, 2007 and 2010)

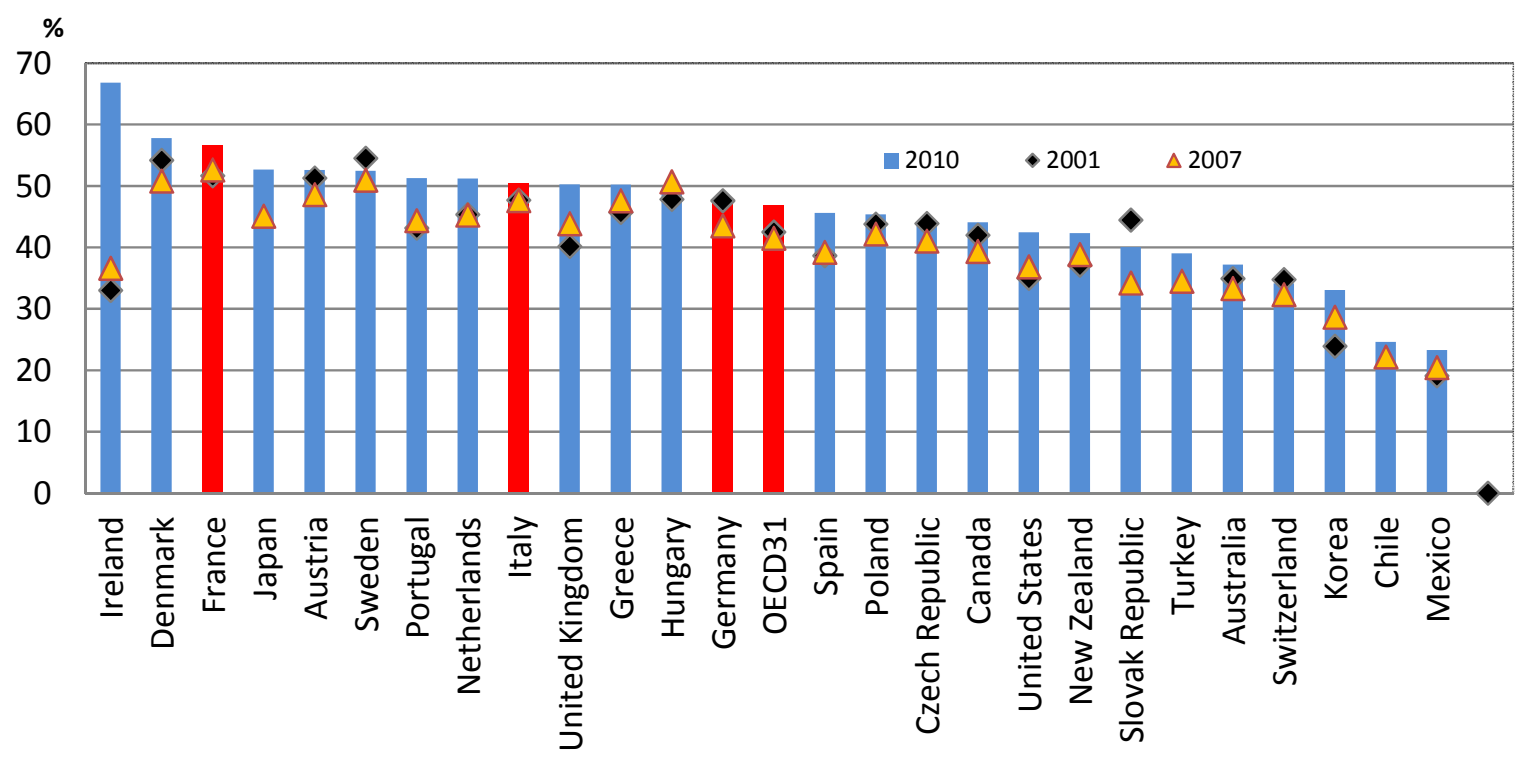


Figure 32. Employment in general government as a percentage of the labour force (2001 and 2009)

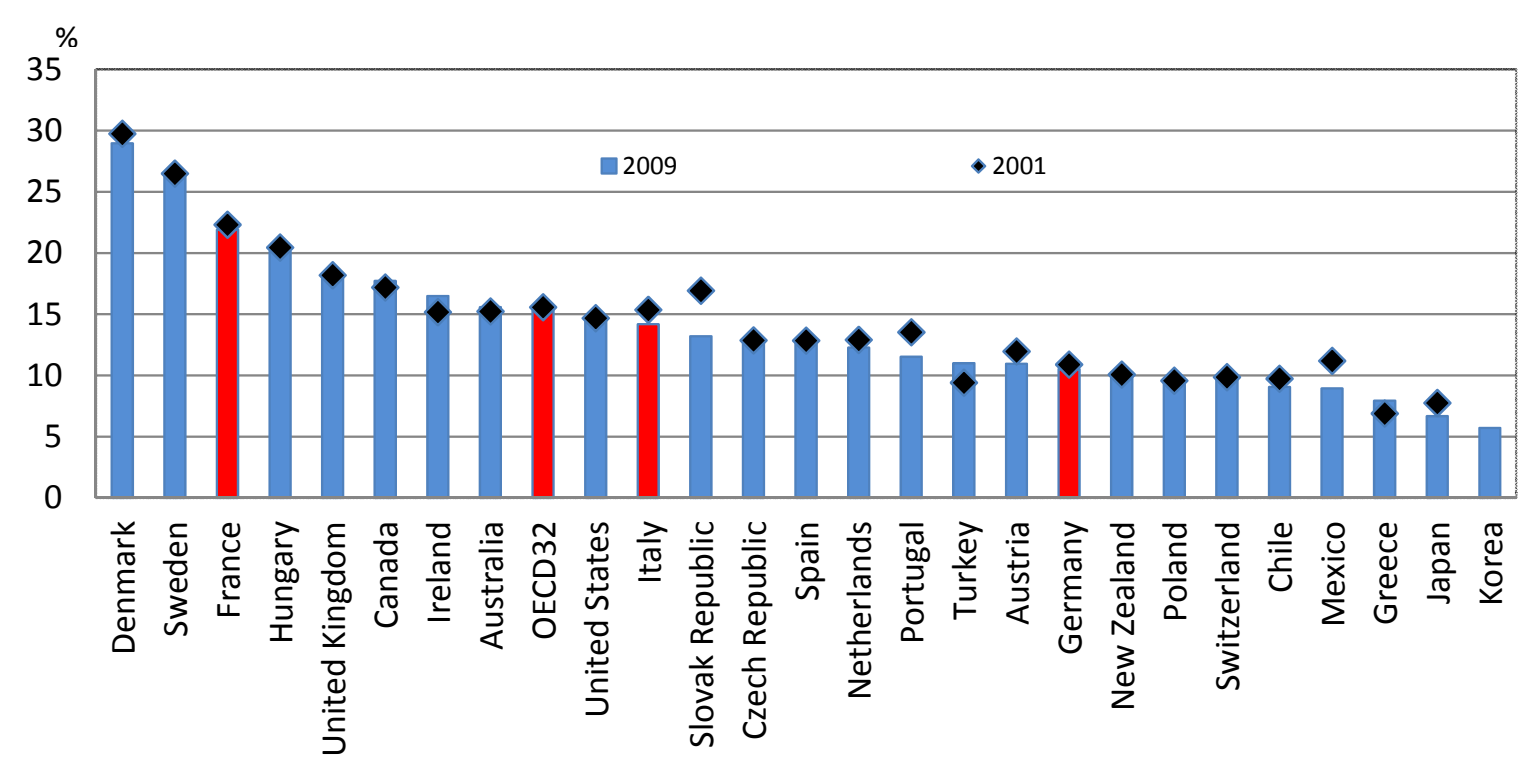




\section{Statistical Annex}

Figure A1. Differences in GDP per capita level, 2011, in \% of 17 best performing OECD countries

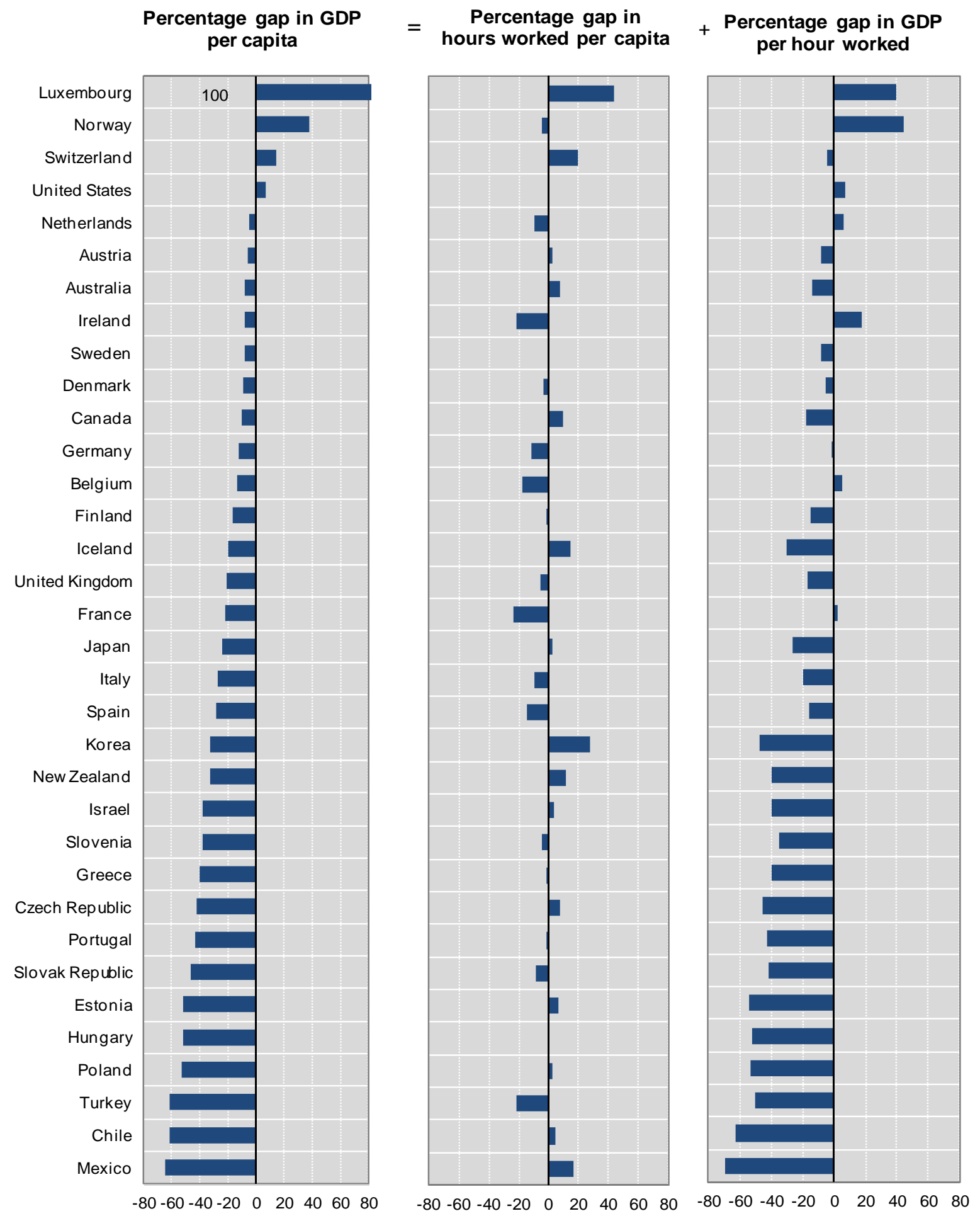

Source : OECD Productivity Database, October 2012 
Figure A2. Sectors' contribution to growth in value added per hour worked, in percentage points

2001-2011

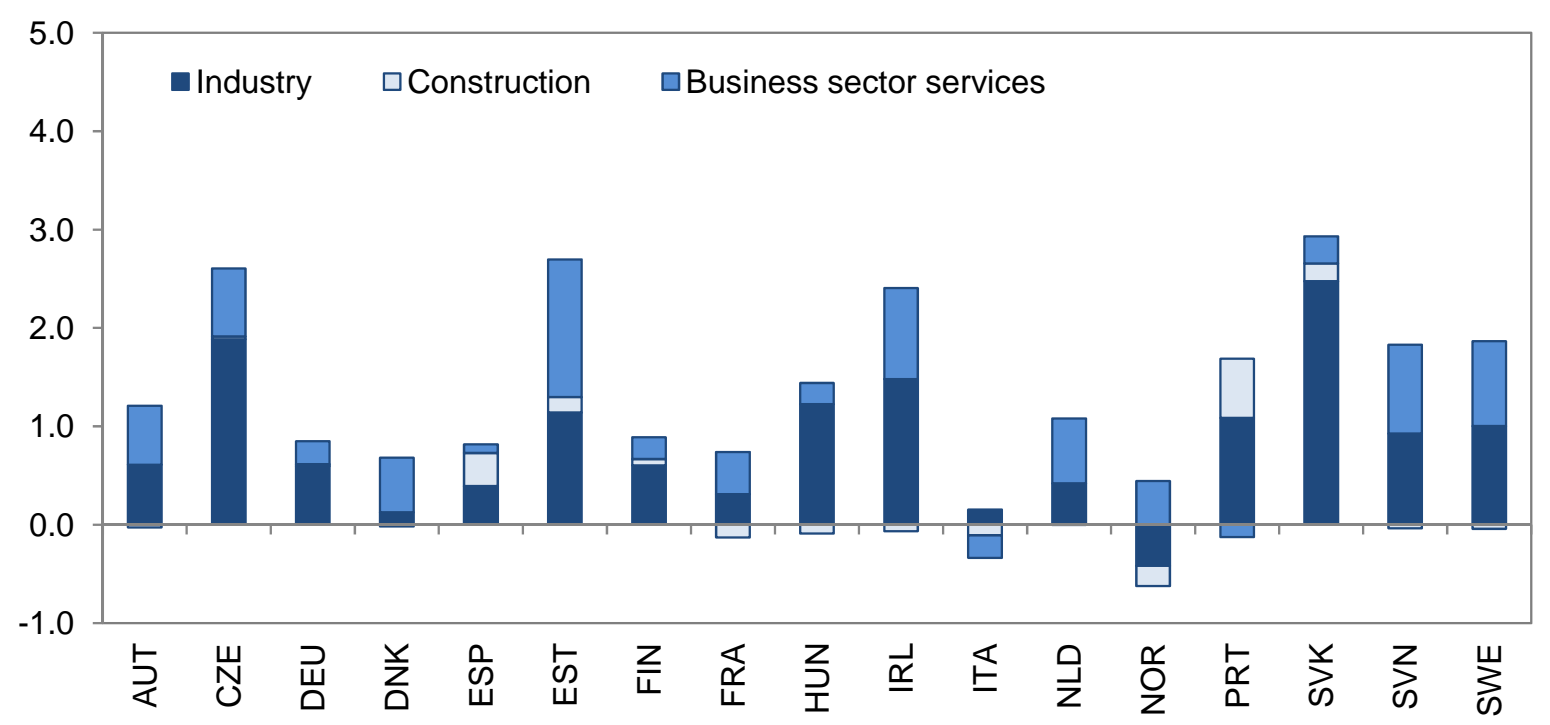

Note: The total is represented by the non-agricultural business sector, excluding real estate services. "Industry" covers manufacturing, mining and utilities. "Business sector services" cover distributive trade, repair, accommodation, food and transport services ; information and telecommunication ; financial and insurance ; professional, scientific and support activities ; arts and entertainment and other repair services.

Source : OECD Annual National Accounts, October 2012 
Figure A3. Decomposition of unit labour costs, industry, annual average growth, in \% 2001-2011

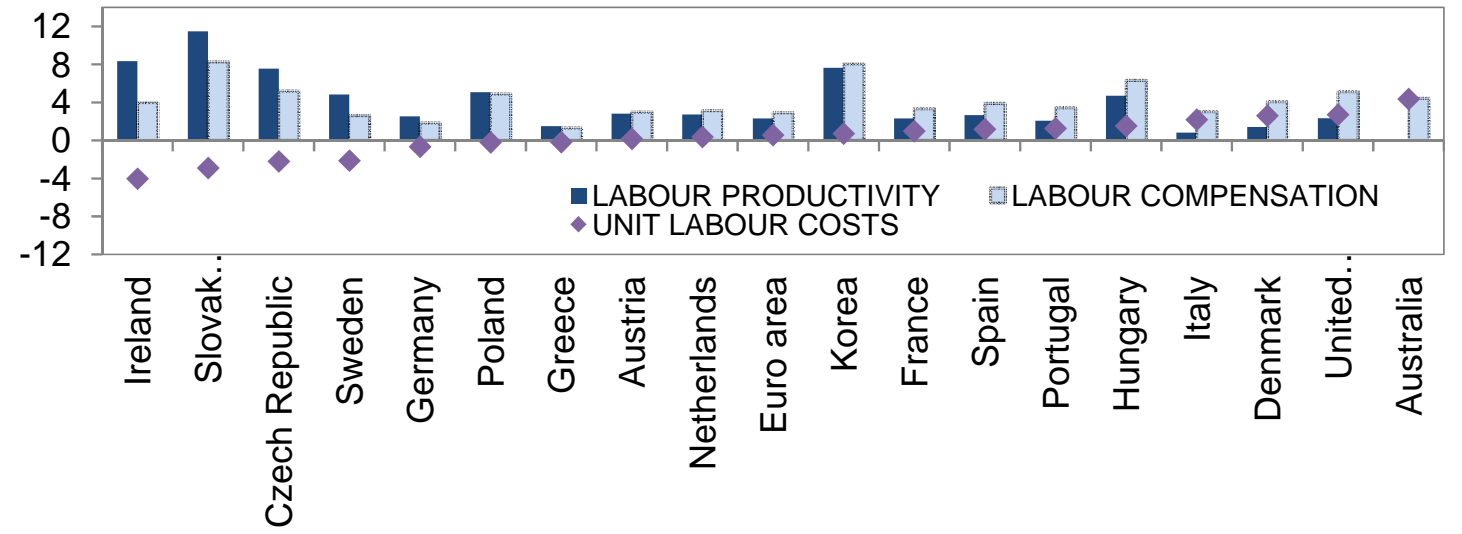

2001-2007

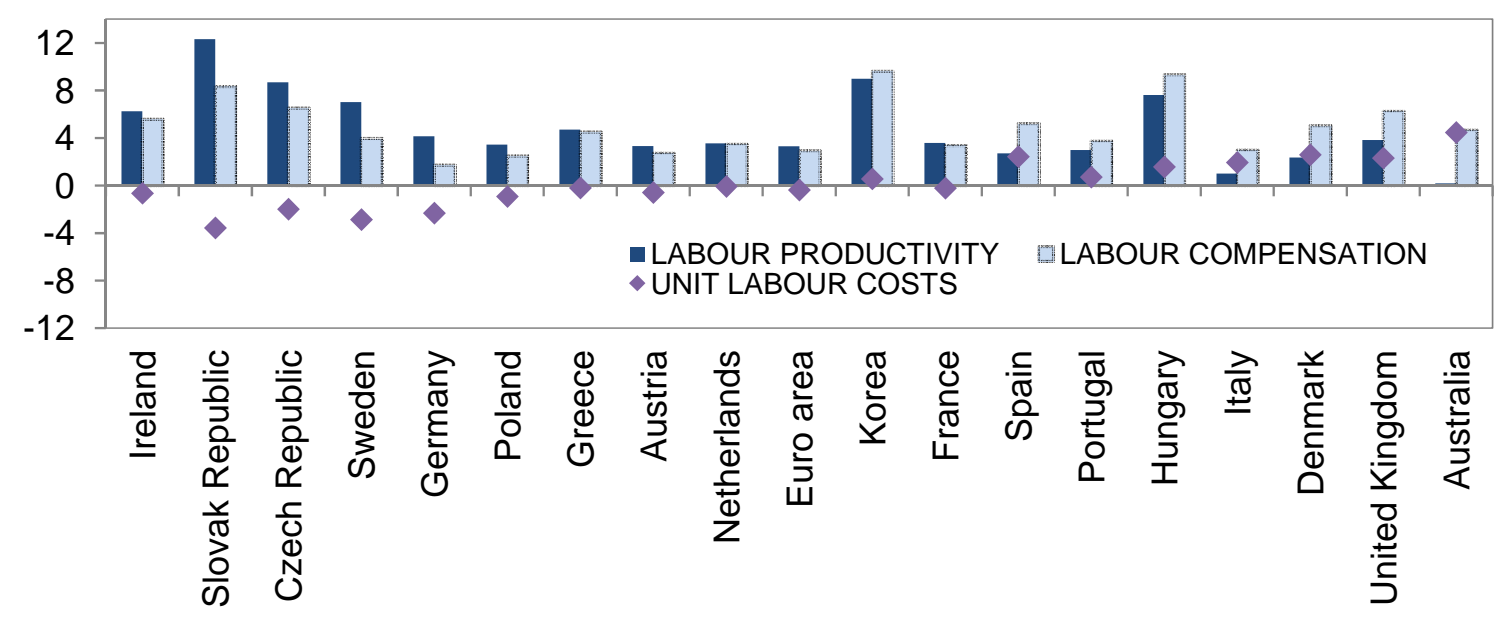

2007-2011

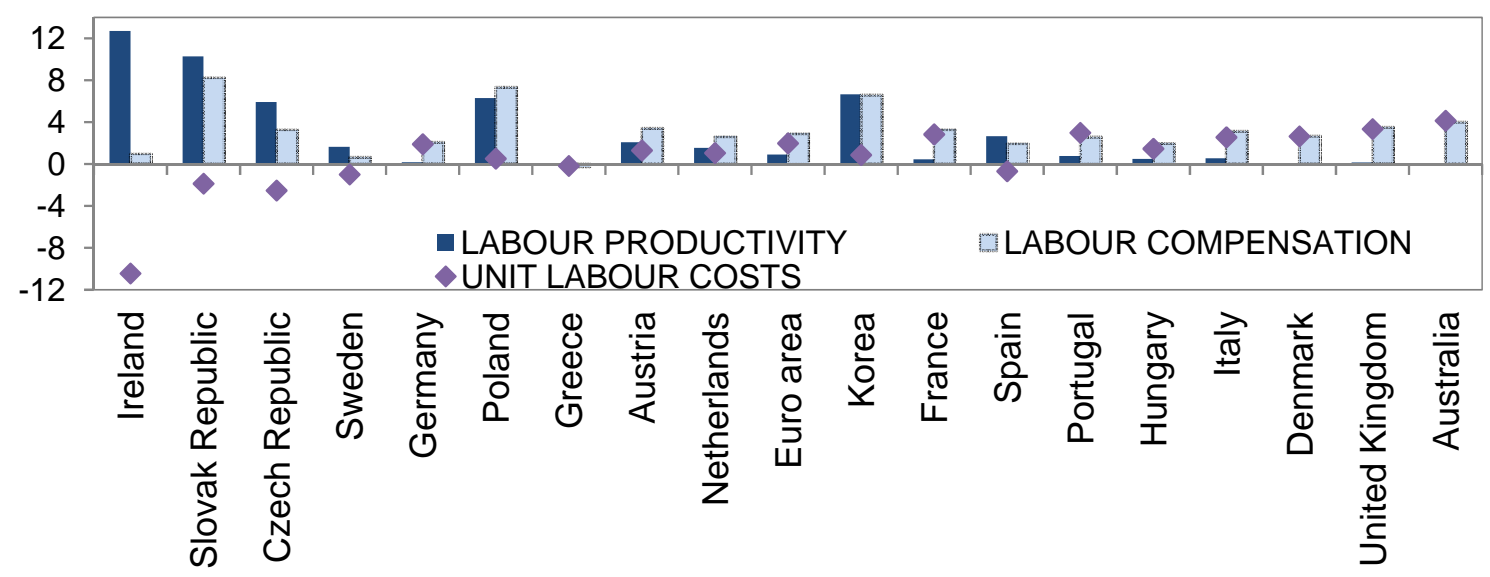

Note: Countries are ranked according to the overall period 2001-2011. Industry covers manufacturing, mining and energy. Information on total hours worked is not available for all countries in all periods and so proxies, such as employees or the numbers of persons employed are used, instead. This means that the labour productivity estimates shown above are not necessarily identical to those sourced from the OECD Productivity Database.

Source : OECD Labour Costs Database, October 2012 
Decomposition of unit labour costs, market services, annual average growth, in \% 2001-2011

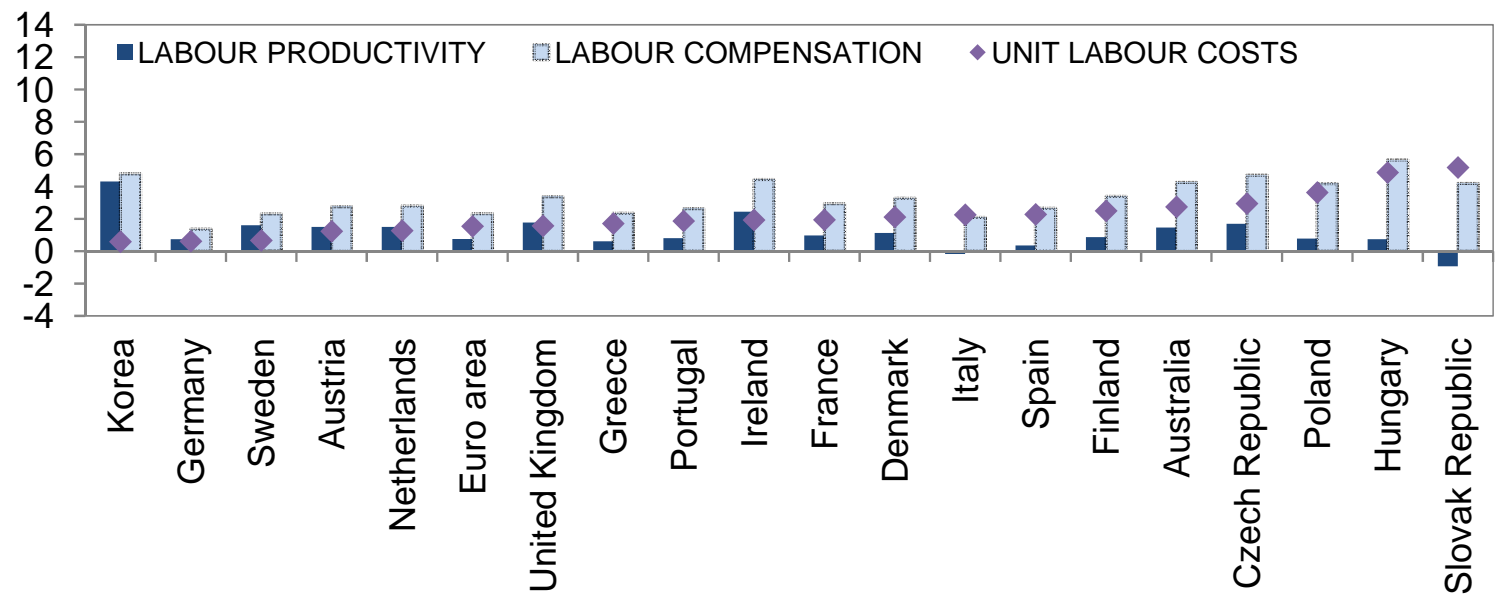

2001-2007

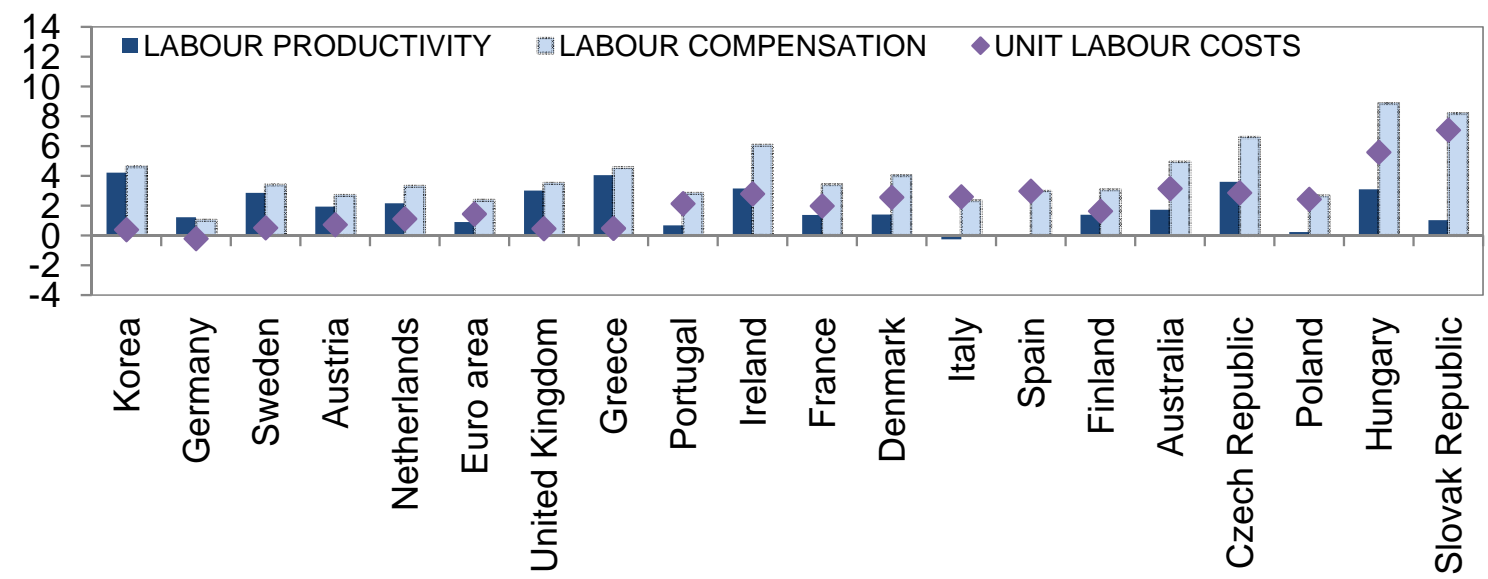

2007-2011

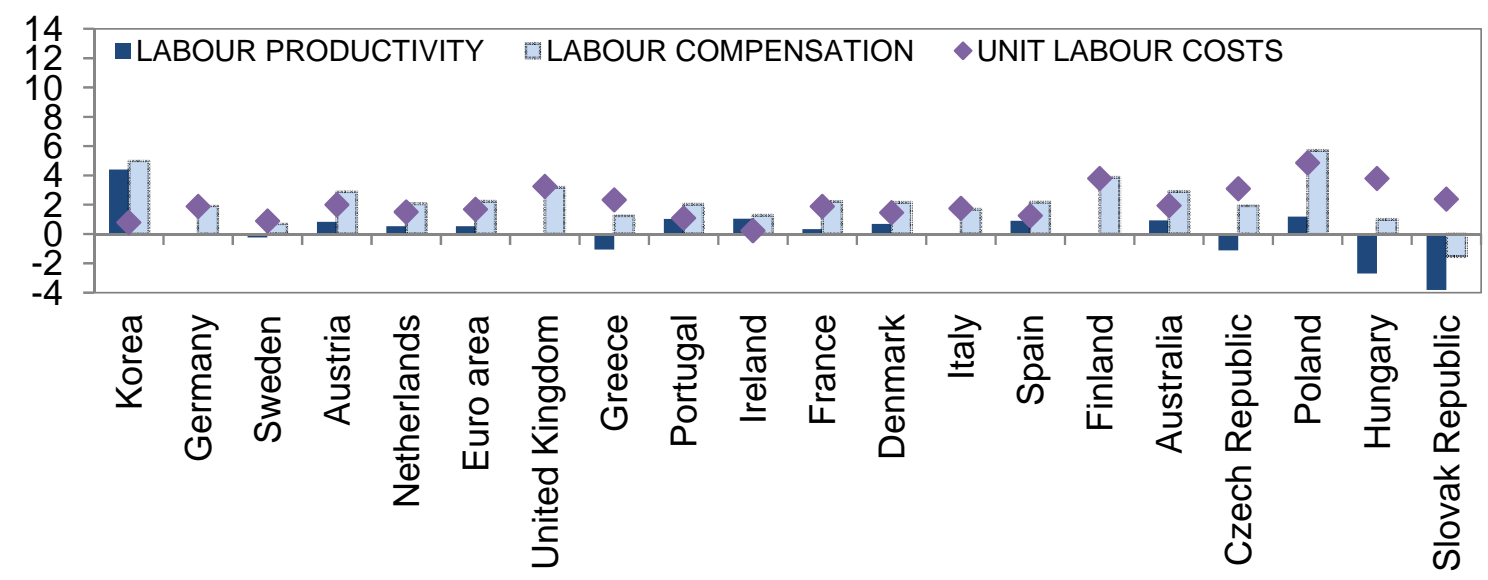

Note : Countries are ranked according to the period 2001-2011. Market Services cover distributive trade, repairs, transport, accommodation; information and communication; financial and insurance; real estate activities ; professional, scientific, technical and support services activities. Information on total hours worked is not available for all countries in all periods and so proxies, such as employees or the numbers of persons employed are used, instead. This means that the labour productivity estimates shown above are not necessarily identical to those sourced from the OECD Productivity Database.

Source : OECD Labour Costs Database, October 2012 


\section{ORGANISATION FOR ECONOMIC CO-OPERATION AND DEVELOPMENT}

The OECD is a unique forum where governments work together to address the economic, social and environmental challenges of globalisation. The OECD is also at the forefront of efforts to understand and to help governments respond to new developments and concerns, such as corporate governance, the information economy and the challenges of an ageing population. The Organisation provides a setting where governments can compare policy experiences, seek answers to common problems, identify good practice and work to co-ordinate domestic and international policies.

The OECD member countries are: Australia, Austria, Belgium, Canada, Chile, the Czech Republic, Denmark, Estonia, Finland, France, Germany, Greece, Hungary, Iceland, Ireland, Israel, Italy, Japan, Korea, Luxembourg, Mexico, the Netherlands, New Zealand, Norway, Poland, Portugal, the Slovak Republic, Slovenia, Spain, Sweden, Switzerland, Turkey, the United Kingdom and the United States. The European Union takes part in the work of the OECD.

OECD Publishing disseminates widely the results of the Organisation's statistics gathering and research on economic, social and environmental issues, as well as the conventions, guidelines and standards agreed by its members.

\section{OECD “Better Policies” Series}

The Organisation for Economic Co-operation and Development (OECD) aims to promote better policies for better lives by providing a forum in which governments gather to share experiences and seek solutions to common problems. We work with our 34 members, key partners and over 100 countries to better understand what drives economic, social and environmental change in order to foster the well-being of people around the world. The OECD Better Policies Series provides an overview of the key challenges faced by individual countries and our main policy recommendations to address them. Drawing on the OECD's expertise in comparing country experiences and identifying best practices, the Better Policies Series tailor the OECD's policy advice to the specific and timely priorities of member and partner countries, focusing on how governments can make reform happen. 
www.oecd.org/france

OECD

2, rue André Pascal, 75775 Paris Cedex 16

Tel.: +33 (0) 145248200 